\title{
Guilty until Proven Guilty: Effective Bail Reform as a Human Rights Imperative
}

Hafsa S. Mansoor

Follow this and additional works at: https://via.library.depaul.edu/law-review

Part of the Law Commons

\section{Recommended Citation}

Hafsa S. Mansoor, Guilty until Proven Guilty: Effective Bail Reform as a Human Rights Imperative, 70 DePaul L. Rev. 15 (2022)

Available at: https://via.library.depaul.edu/law-review/vol70/iss1/3

This Article is brought to you for free and open access by the College of Law at Digital Commons@DePaul. It has been accepted for inclusion in DePaul Law Review by an authorized editor of Digital Commons@DePaul. For more information, please contact digitalservices@depaul.edu. 


\title{
GUILTY UNTIL PROVEN GUILTY: EFFECTIVE BAIL REFORM AS A HUMAN RIGHTS IMPERATIVE
}

\author{
Hafsa S. Mansoor*
}

\begin{abstract}
The continued existence of cash bail as a tool to subjugate the most vulnerable is among the most pressing civil rights issues today. Cash bail morphs criminal convictions from an adjudication of factual and legal guilt to an inquiry into wealth status. It creates an income-based system of differential justice by detaining the poor and freeing the rich. The negative consequences of prolonged detention therefore redound to the jailed-but-poor, distorting the criminal process by encouraging defendants to plead guilty merely to secure release. Although jurisdictions are increasingly reconsidering their bail systems, too many either allow this travesty to continue unimpeded or have enacted putative reforms which transmute inequality without eliminating it, especially through the use of algorithmic risk assessment tools, which-despite being hailed as a panacea-only re-entrench existing biases under a sheen of scientific objectivity. Consequently, this Article seeks to reconceptualize bail reform, moving it from a subjective moral foible to an objective legal mandate using the framework of the international human right of access to justice. It notes the ways in which both cash bail and putative reforms violate the structural and procedural guarantees of access to justice.
\end{abstract}

\section{INTRODUCTION}

The law, in its majestic equality, forbids rich and poor alike to sleep under bridges, to beg in the streets, and to steal their bread.

- Anatole France**

The headlines are littered with the jailed bodies of the innocent-butpoor, who died unable to pay their bail. Sometimes we remember

* J.D. Seton Hall University School of Law; B.A., Webster University. Thank you to Professors Kristen Boon and Bryan Murray for their invaluable support as advisors. I am also deeply grateful to Professor Michael Coenen and Ian Hummell for their generous feedback.

** Anatole France, Trie RED LiLy, 91 (1924) 
their names as a rallying cry for justice, but, more often, they are quietly penciled onto the bottom of the ever-growing list of collateral damage casualties of the American criminal system.

In 2010, Kalief Browder was only sixteen years old when he was accosted by police in the early morning hours on suspicion of stealing a backpack. ${ }^{1}$ His pleas of innocence fell on deaf ears, and he was condemned to a de facto sentence in the form of a $\$ 3,000$ bail. $^{2}$ Because his family could not afford to buy his freedom, and he refused to plead guilty to a crime he did not commit, he was jailed at Rikers Island for more than a thousand days, where, in his words, he was "robbed of [his] happiness."3 Kalief Browder was twenty years old when prosecutors pronounced they were "unable to meet [their] burden of proof at trial" and were forced to drop all charges against him. ${ }^{4}$ And he was only twenty-two years old in 2015 when he hanged himself, "[h]aunted by the mental and physical torture he was subjected to by officers at Rikers Island [and by his] two years of solitary confinement." 5 Kalief Browder was never convicted of a crime. ${ }^{6}$ His death catalyzed a conversation on the violence of cash bail and the purgatory of Rikers. ${ }^{7}$ But cash bail still thrives, and Rikers' gates are not yet closed. ${ }^{8}$

On July 10, 2015, Sandra Bland, a twenty-eight year old Black woman, was pulled over for failing to signal a lane change. ${ }^{9}$ The stop soon became a verbal altercation ${ }^{10}$ and ended with Sandra Bland be-

1. Jennifer Gonnerman, Before the Law, Tril Ni:w Yolkis (Sept. 29, 2014), https:/www.new yorker.com/magazine/2014/10/06/before-the-law.

2. Id. Browder was charged with robbery, grand larceny, and assault, despite having been given assurances he " 'most likely [] [could] go home"" without anything coming of the arrest. Id.

3. Id.

4. Id.

5. Deion Browder, My mom died trying to preserve the legacy of her son. Keeping kids out of solitary will preserve hers., USA TODAY (Apr. 23, 2019, 10:24 PM), https://www.usatoday.com/ story/opinion/policing/ spotlight/2019/04/23/kalief-browder-suicide-solitary-confinement-venidabrowder-policing-the-usa/3540366002/.

6. Id.

7. Id.

8. Proposals to shutter Rikers had been in the works for years without success. Matthew Haag, 4 Jails in 5 Boroughs: The $\$ 8.7$ Billion Puzzle Over How to Close Rikers, N.Y. Timis (Sept. 4, 2019), https:/www.nytimes.com/2019/09/04/nyregion/rikers-island-jail-closing.html (last updated Sept. 6, 2019). But on October 17, 2019, the New York City Council finally approved a plan to close Rikers by 2026 and replace it with four smaller jails in Brooklyn, Manhattan, Queens, and the Bronx. Aaron Randle, Rikers Island: The Closing of the Notorious Jail, Explained, N.Y. TIMIs (Oct. 18, 2019), https:/www.nytimes.com/2019/10/18/nyregion/nyc-newsrikers-island.html.

9. David Montgomery, The Death of Sandra Bland: Is There Anything Left to Investigate?, N.Y. TrMl:s (May 8, 2019), https://www.nytimes.com/2019/05/08/us/sandra-bland-texasdeath.html.

10. Adeel Hassan, The Sandra Bland Video: What We Know, N.Y. TIM]:s (May 7, 2019), https:/www.nytimes.com/2019/05/07/us/sandra-bland-brian-encinia.html. The state trooper took 
ing custodially arrested and taken to jail. ${ }^{11} \mathrm{~A}$ magistrate set bail at $\$ 5,000$, of which she needed to pay $\$ 500$ (ten percent) to a bail bondsman for her freedom. ${ }^{12}$ But her family was unable to raise the few hundred dollars. ${ }^{13}$ On July 13, 2015-just three days after her traffic stop-Sandra Bland was found hanging in her jail cell, an apparent suicide. ${ }^{14}$ Her family was still scrambling to collect the money when they learned of her death. ${ }^{15}$ Two years later, Texas passed the "Sandra Bland Act," which, inter alia, mandates release of defendants with mental illnesses or disabilities on personal bond ${ }^{16}$ but makes no broader reforms to Texas's bail system. ${ }^{17}$

Janice Dotson-Stephens, sixty-one, was arrested on July 18, 2018 for misdemeanor trespass in southern Texas. ${ }^{18}$ Despite having a known history of schizophrenia and despite the purported protections of the Sandra Bland Act, Janice Dotson-Stephens was not released or offered mental health treatment. ${ }^{19}$ Instead, she was held on a $\$ 300$ bond,

issue with Ms. Bland's frustration with having been stopped for a minor incident and her refusal to put out a cigarette; he ordered her out of the car, threatening to " "yank [her] out" "or " light [her] up" " with his stun gun if she did not comply. Id. Ms. Bland ultimately exited her car voluntarily but struggled and yelled profanities as she was being handcuffed and arrested. Id. Cellphone video and dashcam footage suggest the Texas state trooper was never in danger. $I d$.

11. Id.

12. Sharon Grigsby, Another outrage in Sandra Bland injustice: She couldn't find $\$ 500$ bail, Dall. Morning News (July 27, 2015, 5:38 PM), https://www.dallasnews.com/opinion/2015/07/ 27/another-outrage-in-sandra-bland-injustice-she-couldn-t-find-500-bail/.

13. Id.

14. Montgomery, supra note 9. Speculation swirled whether Ms. Bland's death was a homicide or suicide, but county officials declared it a suicide on July 23, 2015 after Ms. Bland's autopsy revealed the markings on her neck were consistent with suicide, and she had no signs of a violent struggle on her head, neck, or hands. Id. Many, including members of Ms. Bland's family, still believe her death was a homicide. Tracy Swartz, Sandra Bland documentary: What we learned about the Chicago-area native and her mysterious death, CHI. TRाв. (Dec. 4, 2018, 8:40 AM), https://www.chicagotribune.com/entertainment/tv/ct-ent-sandra-bland-documentary-20181203story.html.

15. Grigsby, supra note 12.

16. S.B. 1849, 85th Legis. (Tex. 2017). If the defendant is released under the Act, it will be conditioned on their seeking mental health treatment while released. Id. Release can be denied if the state makes a showing of good cause for detention. Id. See also Johnathan Silver, Texas Gov. Abbott signs "Sandra Bland Act" into law, Tex. TriB. (June 15, 2017, 4:00 PM), https:// www.texastribune.org/2017/06/15/texas-gov-greg-abbott-signs-sandra-bland-act-law/.

17. See id. for information on limited exceptions for those with mental illnesses. For other criticisms of the omissions in the Sandra Bland Act, see Michael Barajas, The Sandra Bland Act Was Stripped of the Provision That Could've Prevented Her Arrest. Now It Has a Chance., Tex. Observer (Apr. 5, 2019, 12:58 PM), https://www.texasobserver.org/the-sandra-bland-act-wasstripped-of-the-provision-that-couldve-prevented-her-arrest-now-it-has-a-chance/.

18. Pamela Kirkland, Family tries to understand how mom was jailed for 5 months and died before they knew she was there, CNN (Dec. 21, 2018, 10:11 AM), https://www.cnn.com/2018/12/ 19/us/bexar-county-jail-death-janice-dotson-stephens/index.html.

19. Michael Barajas, 'Ignored to Death' in the Bexar County Jail, Tex. Observer (Jan. 4, 2019), https://www.texasobserver.org/ignored-to-death-in-the-bexar-county-jail/. A judge had or- 
meaning payment of ten percent-only $\$ 30$ - would have bought her release. ${ }^{20}$ Despite the low bail amount and the minor offense for which she was arrested, Janice Dotson-Stephens was imprisoned for nearly five months. ${ }^{21}$ She died in jail. ${ }^{22}$ No one had ever visited her, not even her court-appointed lawyer. ${ }^{23}$

Layleen Cubilette-Polanco, a twenty-seven year old Afro-Latina transgender woman, was arrested on misdemeanor charges on April $13,2019 .{ }^{24}$ She was unable to make her $\$ 500$ bail and was sent to Rikers Island. ${ }^{25}$ There, Layleen Cubilette-Polanco was placed in solitary confinement, ${ }^{26}$ even though Rikers regulations purportedly forbid the use of punitive segregation on an inmate with a serious mental or psychiatric condition and even though Rikers knew Layleen Cubilette-Polanco had both schizophrenia and epilepsy. ${ }^{27}$ Three months after being sent to Rikers, she was found unresponsive in her cell and was pronounced dead nearly three hours later, ${ }^{28}$ likely as a result of an epileptic seizure during which she was not supervised or aided. ${ }^{29}$ Layleen Cubilette-Polanco's death revived the conversations on cash bail and Rikers that started with Kalief Browder's death years

dered she undergo psychiatric evaluation a month after her arrest, but such evaluation was still "pending" when she died. Id.

20. $I d$.

21. Id.

22. $I d$.

23. Id. The first time her family was notified of her incarceration was when they needed to collect her body. Id.

24. Compl. at II 25-26, Polanco v. City of New York, No. 1:19-cv-04623 (E.D.N.Y. Aug. 12, 2019); see also Casey Quinlan, Layleen Cubilette-Polanco died at Rikers Island. Her family wants justice., ThinkProgress (Aug. 13, 2019, 4:37 PM), https://thinkprogress.org/family-of-transwoman-who-died-at-new-yorks-rikers-island-files-suit-e07436e43095/.

25. Complaint, supra note 24 , at 9.

26. Rikers officials deny Rikers uses solitary confinement and allege that Ms. Polanco was placed in a "restrictive housing unit." Emanuella Grinberg et al., She was sent to Rikers Island because she couldn't pay $\$ 500$ bail. Now, she's dead and her family wants answers, CNN (June 13, 2019, 6:20 PM), https:/www.cnn.com/2019/06/11/us/transgender-woman-dies-rikers-island/ index.html.

27. Complaint, supra note 24 , at $\$ 927-39$

28. Id. 9 45-52. Reports differ whether corrections officers provided Ms. Polanco with any medical support after finding her unresponsive, or if she was left alone in her cell until she was pronounced dead hours later. Compare id. (arguing officers "took no action to get Layleen medical attention" when they found her unresponsive and instead left her alone in her cell until returning two hours later to find her dead and alleging that, by that point, "[s]he had been dead so long that first responders found her body cold to the touch"), with Grinberg et al., supra note 26 (recounting that Department of Corrections officials stated Ms. Polanco was provided medical care as soon as she was found unresponsive, which continued through when she was pronounced dead).

29. Complaint, supra note 24 , at $9153-55$. 
prior. ${ }^{30}$ But, cash bail still thrives, and Rikers' gates are not yet closed. $^{31}$

The haunting similarities between the stories of Kalief Browder, Sandra Bland, Janice Dotson-Stephens, and Layleen Cubilette-Polanco-and especially their tragic ends-are a chilling testament to both the dangers of cash bail and the persistence of those dangers. And while these deaths may be exceptional, tragedy is still the rule. It is far from anomalous for those held on bail to lose their housing and custody of their children, even if a judge ultimately decides to dismiss their case.$^{32}$ It is also far from anomalous for those held on bail to lose weeks of income, miss holidays with their family, and suffer permanent physical damage from violence during their incarceration, even if prosecutors drop all charges against them as baseless. ${ }^{33}$ And, it is far

30. Grinberg et al., supra note 26.

31. Nearly two weeks prior to Ms. Polanco's arrest, New York passed legislation ending cash bail for most misdemeanors and nonviolent felonies, but it was subsequently rolled back. Id.; Carl Campanile \& Bernadette Hogan, As early voting begins in NY, bail reform emerges as key issue in state races, N.Y. PosT (Oct. 23, 2020, 6:00 PM), https://nypost.com/2020/10/23/bail-reform-emerges-as-key-issue-in-ny-as-voting-begins/. Some suggest Ms. Polanco would not have been held on bail had she been arrested after its enactment. Grinberg et al., supra note 26. For more on New York's bail reform laws, see Michael Rempel \& Krystal Rodreiguez, New York's Bail Reform Law: Major Components and Implications, Ctr. C.. Innovation (Apr. 5, 2019), https:/www.courtinnovation.org/ publications/bail-reform-NYS. See supra, note 8 and accompanying text regarding the current state of Rikers.

32. The night of March 18, 2014, Adriana realized she was running low on diapers for her twoyear-old daughter. Nick Pinto, The Bail Trap, N.Y. Trmes (Aug. 13, 2015), https:// www.nytimes.com/2015/08/16/magazine/the-bail-trap.html. She was living at a shelter for domestic violence survivors and had a friend at the shelter look after her daughter while she ran to the store for the diapers. Id. A shelter staff member saw Adriana leaving without her daughter and called the police; by the time Adriana returned, diapers in hand, the police were waiting for her. Id. The police arrested Adriana for endangering the welfare of a child and turned her daughter over to Children's Services. Id. Even though Adriana had no criminal record or prior failures to appear, the prosecutor asked bail to be set at $\$ 5,000$, citing Adriana's "previous contact with the Administration for Children's Services"; the prosecutor failed, however, to note that the "previous contact" was not because she abused or neglected her child but because of her boyfriend's violence - the same behavior that led Adriana to the domestic violence shelter in the first place. Id. But, during arraignment, the judge neither heard from Adriana's friend to corroborate that Adriana had not left her daughter alone nor pursued the details of the Children's Services report. Id. Instead, the judge set bail at $\$ 1,500$ - effectively consigning Adriana to Rikers. Id. While Adriana was jailed, she lost her bed at the shelter, and her daughter was placed in foster care. After two weeks of hearings, Adriana was released without bail on condition she complete weekly "life-skills coursework"; and it took another nearly two months for the judge to agree to dismiss Adriana's case if she was not arrested for the next six months. Id. Five months after her arrest, Adriana was still fighting to regain custody of her daughter. Id.

33. On November 19, 2014, Tyrone Tomlin, fifty-three, was heading home, when police stopped him outside the convenience store where he had just bought a soda wrapped in a paper bag and a straw. Id. The officers saw Mr. Tomlin's bagged soda and straw and asked him if he "had anything on him that he shouldn't." Id. Mr. Tomlin said " No, you can check me, I don't have nothing on me" "; the officer then patted Mr. Tomlin down, even inspecting his socks. Id. Suddenly, Mr. Tomlin was being handcuffed. Id. When he asked why, the officer told him " drug 
from anomalous for those held on bail to be fired from their jobs, miss the birth of a child, and nearly lose their home and vehicle before finally accepting a plea just to go home. ${ }^{34}$

The United States has the world's highest total number of pretrial detainees. ${ }^{35}$ On any given day, American jails detain approximately a half million people pretrial-nearly double the next highest country ${ }^{36}$ - and these numbers are only growing. ${ }^{37}$ Indeed, approximately sixty percent of all jail inmates in the U.S. are unconvicted, legally innocent individuals awaiting court action on the charges against

paraphernalia." Id. Astonished, Mr. Tomlin repeated, "Drug paraphernalia?"; the officer "'open[ed] up his hand and show[ed him] the straw." Id. Unfortunately, Mr. Tomlin had several dozen low-level nonviolent misdemeanor priors and two decades-old felonies, so the prosecutor refused to drop the charges. Further, the evidence lab was unable to test the straw for drug residue expediently. So, when Mr. Tomlin refused to plead guilty, the judge set bail at $\$ 1,500$. Id . Because Mr. Tomlin was living paycheck-to-paycheck, he was unable to pay for his freedom and was sent to Rikers Island. $I d$. While there, he was graphically beaten, leaving his left eye swollen shut and his "face monstrously misshapen." Id. After three weeks at Rikers, Mr. Tomlin was haled into court and informed that, two and a half weeks prior, lab analysis had revealed no controlled substances were present on the straw. Id. Having lost three weeks of income, been subjected to "brutal physical violence," and missed family Thanksgiving dinner-all over a wrongful arrest—all charges against him were dropped. Id. Almost a year later, Mr. Tomlin's eye was still askew and his gaze blurry and unfocused; he also continued to suffer pains in his eye and head from the abuse at Rikers. $I d$.

34. Curry v. Yachera, 835 F.3d 373, 377 (3d Cir. 2016). Joseph Curry was charged with two misdemeanors for allegedly collecting $\$ 130.27$ worth of items at Wal-Mart and using a receipt he found in the parking lot to return them for cash. $I d$. at 376 . "His bail was set at $\$ 20,000$." Id. at 377. He was unable to post bail and-during his resulting months of imprisonment-"he missed the birth of his only child, lost his job, and feared losing his home and vehicle." Id. Ultimately, he pled "nolo contendere in order to return home ... [even though he] maintained his innocence throughout the criminal proceedings ..." Id. Nonetheless as part of his nolo plea, Mr. Curry was made to pay $\$ 130.27$ in restitution and the costs of his prosecution, sentenced to two years' probation, and barred from bringing a malicious prosecution claim for what Third Circuit Judge Michael Chagares called "the potentially unconstitutional prosecution that landed him in jail in the first place." Id.

35. Oplen Soc'y Jusil. Initintive: \& U.N. Dizv. Program, Thi: Sochoiconomic: Impac:y of Pritrial. Detention: A Gigbal. Campaign for Prittriat. Justici: Rizororit 16 (Feb. 2011), available at https:/www.justiceinitiative.org/publications/socioeconomic-impact-pretrial-detention. The United States also has the fourth highest rate of pretrial detention in the world $(n=158 /$ $100,000)$. Id.

36. Will Dobbie et al., The Effects of Pretrial Detention on Conviction, Future Crime, and Employment: Evidence from Randomly Assigned Judges, 108 Aм. Eс⿳N. RI:v. 201, 201 (2018).

37. Emily Leslie \& Nolan G. Pope, The Unintended Impact of Pretrial Detention on Case Outcomes: Evidence from New York Cite Arraignments, 60 J.L. \& E( (ON. 529, 530 (2017) ("The number of individuals detained pretrial is also growing, with an increase of over 20 percent between 2000 and 2014." (internal citations omitted)). See also RAm SubramANiAn h:i ai.., Vira Inst, of Justici, Incarchiration's Front Door: Thi: Misusi: of Jails in America 29 (2015) (noting the decrease in the number of felony defendants released on their own recognizance from 1990 to 2009 , coupled with a concurrent $43 \%$ increase in bail amounts during the same time period). 
them. ${ }^{38}$ More than half of these unconvicted detainees spend "at least a month in jail, and one-quarter of unconvicted [detainees] spend between two and six months [in jail]." 39 Further, of these detainees, a significant percentage-whether held on felony or misdemeanor charges-remain behind bars solely because of their inability to pay bail, even when their bail amounts are relatively small. ${ }^{40}$ And these detainees can suffer devastating consequences, personally and legally, as a result of their inability to purchase their release. ${ }^{41}$

The bail system was created to facilitate justice to ensure that those who are factually and legally ${ }^{42}$ guilty do not elude justice by either running from the law or perpetrating additional crimes. But, instead, it impedes justice. It frustrates the adjudication of factual guilt by creating a tiered system of differential justice that detains individuals primarily, if not exclusively, on the basis of their wealth status. In other words, when a judge finds a defendant's case to be concerning enough to necessitate bail as a restraint on their liberty, wealthy defendants are able to post even large bail amounts (which signify greater concerns as to the severity of their charges or the likelihood they will flee), return home, and reap the benefits of such release. ${ }^{43}$ On the other hand, poor defendants are unable to post even petty cash bails, which signify much lesser concerns, and they suffer the consequences of continued detention. ${ }^{44}$ Such differential detention distorts criminal sentencing. Individuals who are detained pretrial have a strong incentive to secure their release and return to their homes, families, and jobs; this pressure facilitates the most insidious facets of plea bargain-

38. Todd D. Minton, Bureau of Just. Stat., U.S. Dept. Just., Jail Inmates at Midyear 2010 - Statistical TABles 1 (2011).

39. Alexandra Natapoff, Misdemeanors, 85 S. CAL. L. REv. 1313, 1322 (2012).

40. See infra notes $101-13$ and accompanying text.

41. See infra notes $136,138-50$, and 152-74 and accompanying text.

42. This paper defines convictions, factual, and legal guilt as distinct concepts: "convictions" refers to the verdict in a criminal proceeding; "factual guilt" refers to whether the allegations against a defendant truly happened (i.e., looking only at the time period prior to any arrest, charges, or legal proceedings); and "legal guilt" refers to whether a prosecutor can and did prove the charges against a defendant beyond a reasonable doubt. In other words, a defendant can be found guilty by a jury of first-degree murder (i.e., be convicted) when the homicide was, in fact, committed by someone else entirely (i.e., be factually innocent). Or, that same defendant may have pleaded guilty to first degree murder (i.e., been convicted) and have been responsible for the homicide (i.e., be factually guilty), but the evidence should only have led to a vehicular homicide conviction when the burden of proof was properly applied (i.e., be legally innocent of first degree murder). In a truly just system, these three concepts would align in each criminal proceeding; such a system would not convict the factually guilty, and it would equally protect the factually guilty but legally innocent from conviction. Thus, where these concepts do not align, the system has failed.

43. See infra notes 114-16 and accompanying text.

44. See infra notes 114-16 and accompanying text. 
ing by encouraging pretrial detainees to accept guilty pleas, regardless of their factual or legal guilt, solely to obtain release and go home.

Finally, existing bail reform regimes-which overwhelmingly purport to move from a resource-based bail system to a risk-based system in which individuals are allegedly held pretrial due to their dangerousness rather than their poverty - fail to remedy these underlying harms. Risk-based assessments inherently rely on existing biased criminal system data to attempt to predict an individual's likelihood of recidivating or fleeing, and they have consequently been empirically shown to strongly correlate with race. Thus, cash bail undermines access to justice. ${ }^{45}$ It creates a system of jail for the poor and justice for the rich.

International human rights law affords every individual an inherent right to access justice ${ }^{46}$ - meaning that cash bail's failings are not merely a moral travesty but potentially an international human rights violation. The human right of access to justice provides all individuals a right to court access and due process to adjudicate their guilt. ${ }^{47}$ This paper aims to reconceive of cash bail within the normative framework of the international human right of access to justice. Elevating bail to the international stage and framing it in the rhetoric and principles of human rights both lends it more gravity and converts it from a subjective, partisan moral foible to an objective, nonpartisan legal concern. Thus, human rights norms can be a compelling tool for advocates for bail reform, ${ }^{48}$ especially because the norms serve the expressive function of announcing the renewed exigency of effective bail reform. ${ }^{49}$

45. See infra notes 199-205, 209-15 and accompanying text.

46. See infra notes 54-56, 59-61 and accompanying text.

47. See infra 59-60 and accompanying text.

48. This is less to encourage bail reform advocates to seek redress before a national or international tribunal on the basis that cash bail violates positive U.S. international legal obligations; and more to say that, normatively, the justice and fairness arguments which motivate bail reform are rooted in more fundamental, internationally transcendent values than partisan public policy agendas. Consequently, advocates can derive added value from human rights as a framing mechanism for their clarion call, even if they cannot take the U.S. to court.

49. Many scholars recognize that even when a human rights treaty is not ratified or a law is not fully executed, the act of signing the law or treaty itself carries expressive value which signals a certain societal understanding of the underlying regulated behavior. See, e.g., Ryan Goodman \& Derek Jinks, Measuring the Effects of Human Rights Treaties, 14 EuR. J. INT'I. L. 171, 182 (2003) ("[H]uman rights treaties serve both a (global) expressive function and a (domestic) constitutive function ... That is, even if ratifications are directly associated with negligible or deleterious effects in particular states, on the whole such treaties can have 'a widespread effect on the practices of all nations by changing the discourse about and expectations regarding those rights.'"); Cass R. Sunstein, On the Expressive Function of Law, 144 U. PA. L. Rı:v. 2021, 2027-28 (1996) ("A society might identify the norms to which it is committed and insist on those norms via law, even if the consequences of the insistence are obscure or unknown. A society might, for example, insist on an antidiscrimination law for expressive reasons even if it does not know whether the law actually helps members of minority groups... The point bears on the 
Part I explores the parameters of access to justice as a human right. Part II briefly summarizes the process and procedure of bail before describing the two primary ways in which cash bail undermines access to justice. First, cash bail creates an income-based system of differential justice by detaining the poor and freeing the rich. ${ }^{50}$ Second, it distorts criminal sentencing by facilitating the most insidious facets of plea bargaining. Together, these mechanisms violate defendants' human rights. Part III discusses how risk-based bail reforms, which rely on algorithmic risk assessment tools to identify defendants likely to reoffend or flee if released, fail to promote access to justice by effectively swapping wealth-based classifications for race-based ones. ${ }^{51}$ This Part especially focuses on New Jersey's 2017 bail reformswidely hailed as one of the most comprehensive reforms in the country-to illustrate the continued deficiencies in "reformed" bail systems. Finally, Part IV concludes by rearticulating the pressing need for effective bail reform.

Before proceeding, it is also worth remembering that a bail determination is but a moment in the criminal system; so, to the extent that the criminal system denies defendants access to justice, the blame does not lie entirely with cash bail. Individuals are only subject to bail because they have been policed, arrested, and charged with an offense; and for pretrial detention to distort criminal sentencing, there

cultural role of law, adjudication, and even Supreme Court decisions."). Here, then, even if declaring the cash bail system to be a human rights violation does not create a cause of action, such a declaration carries the expressive weight of human rights' gravity, legal status, and internationalization.

50. Although this differential justice argument parallels an equal protection-style concern, this paper addresses wealth-based classifications as a human rights violation only insofar as they affect access to justice, and it makes no arguments-equal protection or otherwise-based on the U.S. Constitution, as both of these concerns are outside its scope. The decision not to ground these arguments in the Constitution is two-fold. First, the continuity of bail and its sequelae over the decades suggests that effective reform cannot rest on constitutional principles alone, as it historically has, and a new tool for change must be used to breathe new life into reform efforts. And, second, although the United States considers its Constitution to be a codification of human rights (or at least those human rights it believes legitimate), the language of international human rights conveys a gravity and peril of much more significant concern so that elevating bail into an international human rights framework implicates the most basic guarantees that the world over recognizes as necessary for human dignity in a way that limiting the discourse to a domestic constitutional concern cannot capture.

It is also beyond the scope of this paper to consider human rights norms regarding detention conditions or regarding plea bargaining, independent of bail. For such analysis, however, see Human Rights and Pre-trial Detention: A Handbook of International Standards relating to Pretrial Detention, U.N. Doc. HR/P/PT/3 (1994).

51. . Significant literature has been written to describe the intricacies, efficacy, and fundamental fairness of algorithmic tools in the criminal system, and this paper cannot do the entirety of that body of scholarship justice; instead, the aim of this Part is very narrow: to establish that existing bail reforms are not enough to vindicate defendants' human right of access to justice. 
must be concurrent failures in the adjudication of charges, including in the plea bargaining process and sentencing phase. It is consequently noteworthy that, for instance,

- Recent years have seen countless jurisdictions subject to consent decrees for unconstitutional and discriminatory policing practices; 52

- Substantial racial disparities exist in the arrest rate for many offenses; 53

- Prosecutors typically bring more and harsher charges against defendants of color than White defendants; 54

- Some suggest the plea bargaining system inherently creates a coercive system of cost-benefit analysis that incentivizes undeserved guilty pleas over truthful "not guiltys"; 55

- Certain offenses have historically been sentenced in ways that create gross racial disparities. ${ }^{56}$

Bail is a discrete harm that acutely undermines access to justice, but it is informed by injustices preceding it earlier in the system, and it in

52. For instance, the New Orleans police department was investigated by the United States Department of Justice ("DOJ") in 2011 and subject to a consent decree in 2012. Amended \& Restated Consent Decree Regarding the New Orleans Police Dep't, United States v. City of New Orleans, No. 2:12-cv-01924-SM-JCW (E.D. La. Oct. 2, 2018), E.C.F. No. 565; DOJ, InvI:STgation ol: tim: Ni:w Orienns Police Di:partminc (2011). Newark, New Jersey's police department was investigated by the DOJ in 2014 and subject to a consent decree in 2016. Consent Decree, United States v. City of Newark, No. 2:16-cv-01731-MCA-MAH (D.N.J. Apr. 29, 2016), E.C.F. No. 5; DOJ, Invistigintion of Tine Newniz Polic Drepartmint (2014). The police department in Ferguson, Missouri was investigated by the DOJ in 2015 and subject to a consent decree in 2016. Consent Decree, United States v. City of Ferguson, No. 4:16-cv-00180-CDP (E.D. Mo. Mar. 17, 2016), E.C.F. No. 12-2; DOJ, Invistignilon ol tili: Fiirguson Polici: DI:PARTMI:NT (2015). And the Baltimore police department was investigated in 2016 and subject to a consent decree in 2017. Consent Decree, United States v. Police Dep't of Baltimore City, No. 1:17-cv-00099-JKB (D. Md. Jan. 12, 2017), E.C.F. No. 2-2; DOJ, Invisitication of Thil: Bathimori: City Pol.ici: Dispartimint (2016).

53. Megan Stevenson \& Sandra Mayson, The Scale of Misdemeanor Justice, 98 B.U. L. Rtv. 731, 758-59 (2018). Black individuals are arrested twice more often than their White counterparts for disorderly conduct, drug possession, simple assault, and vandalism; five times more often for prostitution; and ten times more often for gambling. Id. at 759 .

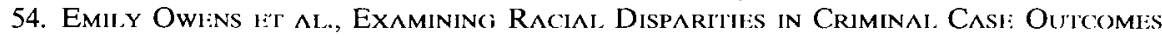
AMong Indigi:n'i Direndoan's in SAN Francisco 18-20 (2017).

55. See generally Lucian E. Dervan \& Vanessa A. Edkins, The Innocent Defendant's Dilemma: An Innovative Empirical Study of Plea Bargaining's Innocence Problem, 103 J. CRIM. L. \& CRIMINOI,OCYY 1 (2013).

56. Crack cocaine, for instance, was sentenced 100 times more harshly than powder cocaine, leading users of crack cocaine-who are more commonly Black and poor-to be sentenced significantly more harshly than users of powder cocaine, who are more often White. DEBORAH J. Vagins \& Jesselyn McCuridy, Amirican Civil. Libiztilis Union, Crac'ks in tile Systi:m: Twinty Years ol: thi: Unjust Federai. Crack Cocaini: Law 2-3 (2006). 
turn informs the quality of justice in subsequent stages of criminal proceedings. ${ }^{57}$ Therefore, this Article does not address all sources of injustice in the criminal system, nor does it contend that resolving the issues with cash bail highlighted here will conclusively ensure access to justice for all defendants. But effectively reforming cash bail does create a meaningful opportunity for sincere change to push the entire system towards justice.

\section{The Human Right of Access to Justice}

The human right of access to justice is, in many ways, a nebulously defined and severely undertheorized right with imprecise and inconsistently delineated boundaries. ${ }^{58}$ Philosophically, it fundamentally represents "the ability of people to obtain just resolution of justiciable problems and enforce their rights, in compliance with human rights standards." 59 Thus, the United Nations ("U.N.") has stated important considerations in ensuring access to justice include: (1) "the independence of the judicial system, together with its impartiality and integrity, as an essential prerequisite for upholding the rule of law and ensuring that there is no discrimination in the administration of justice"; (2) the ability of "the poor and marginalized to seek response and remedies for injustice"; and (3) "challenges in the justice sector such as police brutality, inhumane prison conditions, [and] lengthy pretrial detention."60

57. See, e.g., Natapoff, supra note 39, at 1317 ("[Misdemeanor] convictions are largely a function of being selected for arrest; this is because vulnerable, underrepresented defendants tend to plead guilty even in the absence of evidence.").

58. The exact contours of access to justice have been debated nearly as long as it has been recognized as a fundamental human right. See, e.g., Charles E. Wyzanski, Nuremberg: A Fair Trial? A Dangerous Precedent, THE ATLANTIC (Apr. 1946), https:/www.theatlantic.com/magazine/archive/1946/04/nuremberg-a-fair-trial-a-dangerous-precedent/306492/ (debating the procedural fairness of the Nuremberg trials as a matter of international legal justice and questioning both the impartiality of the tribunal and the effectiveness of the process afforded the defendants).

59. Org. for Econ. Cooperation \& Dev. ("OECD”) \& Opfen Soc'y Found., Legal NeEds Surveys And AcCess to Justice 24, 41 (2019).

60. United Nations \& THE Rule of LAw, Access to Justice, https:/www.un.org/ruleoflaw/ thematic-areas/access-to-justice-and-rule-of-law-institutions/access-to-justice/ (last viewed Sept. 19, 2019). 
Although widely accepted as a fundamental right, ${ }^{61}$ at times, access to justice operates as an "I know it when I see it" right 62 so that scholars have been more consistent in defining what access to justice is not, rather than what access to justice is. Thus, it is uncontroversial that access to justice is denied where access to courts is denied, unwarrantedly delayed, or otherwise obstructed; where judicial process is grossly deficient; where there is a failure to provide procedural guarantees indispensable to the proper administration of justice; or where a manifestly unjust judgment results. ${ }^{63}$ It is also uncontroversial that access to justice affirmatively includes both structural and procedural components (i.e., access to an independent and competent tribunal and certain fair process guarantees). ${ }^{64}$ The confusion results, however, when deciding whether access to justice includes more considerations than these, ${ }^{65}$ what these structural and procedural components mean as concrete rights in practice, ${ }^{66}$ and how the application of access to

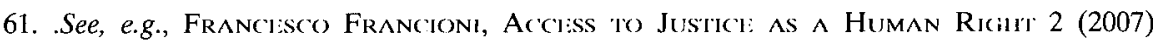
("[A]ccess to justice is guaranteed as a legal right in virtually all universal and regional human rights instruments since the 1948 Universal Declaration [of Human Rights] . . ."); PII:RRF:

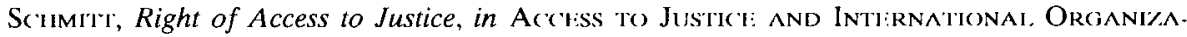

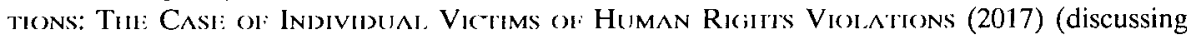
the right of access to justice in domestic tribunals as a potential peremptory or jus cogens norm); Mauro Cappelletti \& Bryant Garth, Access to Justice: The Newest Wave in the Worldwide Movement to Make Rights Effective, 27 BurF. L. RI:v. 181, 185 (1978) ("Effective access to justice can thus be seen as the most basic requirement-the most basic 'human right'—of a modern, egalitarian legal system which purports to guarantee, and not merely proclaim, the legal rights of all."); Stephanie Redfield, Searching for Justice: The Use of Forum Necessitatis, 45 Gr:o. J. IN'I'I. L. 893, 903-04 (2014) (arguing the right of access to justice is customary international law).

62. As a legal phrase, "I know it when I see it" first appeared in Justice Potter's concurrence in Jacobellis v. Ohio, a First Amendment obscenity case, in which he said "I shall not today attempt further to define the kinds of material I understand to be embraced within [hard-core pornography] ... and perhaps I could never succeed in intelligibly doing so. But I know it when I see it, and the motion picture involved in this case is not that." Paul Gewirtz, On "I Know It When I See It", 105 YAI.I: L.J. 1023, 1024 (1996) (citing Jacobellis v. Ohio, 378 U.S. 184, 197 (1964)) (Stewart, J., concurring) (citations omitted) (emphasis added).

63. Francioni, supra note 61, at 11 (citing The Law of Responsibility for Damage Done in their Territory to the Person or Property of Foreigners, 23 AM. J. INI'I. L. 131, 134 (1929)); see also Cappelletti \& Garth, supra note 61, at 185 (recognizing access to justice is denied when individuals cannot get their day in court).

64. See Cappelletti \& Garth, supra note 61 , at 182 ("The words 'access to justice' are admittedly not easily defined, but they serve to focus on two basic purposes of the legal system - the system by which people may vindicate their rights and/or resolve their disputes under the general auspices of the state. First, the system must be equally accessible to all; second it must lead to results that are individually and socially just.").

65. See, e.g., SCHмi'T, supra note 61, at 107 (describing potential "constitutive elements" of access to justice as "the right to effective access to a dispute resolution body, the right to fair proceedings, the right to timely resolution of disputes, the right to adequate redress, and conformity with the principles of efficiency and effectiveness").

66. Jasminka Kalajdzic, Access to Justice for the Wrongfully Accused in National Security Investigations, 27 WINISSOR Y.B. ACCriss JuST. 171, 175-76 (2009) ("Few would deny the impor- 
justice differs in the criminal versus civil context ${ }^{67}$ and in the context of domestic versus international tribunals. ${ }^{68}$

This Article exclusively concerns criminal proceedings before a domestic tribunal and, based on the most indispensable and widely accepted conceptions of access to justice, defines access to justice in terms of criminal defendants' basic rights to a fair trial. Much of the literature on access to justice concerns the rights of individuals to seek redress in a tort-like national or international civil suit when their rights are violated, and in such context, it is widely acknowledged that access to justice includes a right to an "effective remedy." 69 However, no such substantive component attaches in the criminal context. ${ }^{70}$ The civil-context right to an effective remedy inherently presumes an individual plaintiff is seeking redress (i.e., subjecting themselves to judicial process) only because their rights were violated, thus permitting an entitlement to an end outcome. ${ }^{71}$ But criminal defendants do not choose to be the subject of judicial process and have no opportunity to self-select out if they know that they are not deserving of the ultimate outcome. Consequently, the criminal system necessarily concerns the rights of those who deserve prosecution and those who do not, making any entitlement to an end outcome impossible. Instead, the fairness of the outcome of criminal proceedings turns on the fairness of the process and its ability to differentiate the innocent and the guilty. Ergo, the right to an effective remedy is inapt in the criminal context. Rather, access to justice in U.S. criminal proceedings requires that there be a trial procedure (the structural component of access to justice) and that it be fair (the procedural component of access to justice). ${ }^{72}$

tance of access to justice as a foundational principle in a liberal democracy, but how such a principle manifests itself 'on the ground' elicits anything but unanimity.").

67. Compare G.A. Res. 217 (III) A, Universal Declaration of Human Rights, art.8 (Dec. 10, 1948), [hereinafter "UDHR"] (providing for the right to an effective remedy in civil suits for rights violations), with UDHR, art. 11 (providing distinct procedural guarantees like the presumption of innocence in criminal suits).

68. FrAncioni, supra note 61 , at 8 (comparing access to justice in domestic legal systems rather than before international tribunals).

69. FranCIONI, supra note 61 , at $1-3$.

70. Access to justice is undertheorized writ large, but to the extent that scholars have mulled on it, much of the literature concerns this right to a remedy in the civil context; consequently, there is an even more significant dearth of literature conceptualizing access to justice for criminal defendants.

71. Francioni, supra note 61 , at $1-3$.

72. Mark Findlay, Internationalised criminal trial and access to justice, 2 INT'L CRIM. L. REV. 237,244 (2002) ("Access to justice is a universal indicator of trial fairness and rights recognition ..." It can be denied in criminal systems through "delay, expense, lack of proportionality, and differential accessibility."). See also Ralph Henman, Conceptualizing Access to Justice and Vic- 
Regarding the structural component of access to justice, most human rights instruments, including those to which the U.S. is a party, contain provisions describing a criminal defendant's right of equal access to a public hearing before a competent and impartial tribunal to adjudicate the charges against them..$^{73}$ Thus, in essence, the structural component of access to justice in U.S. criminal proceedings concerns the right to court access, "on the premise that courts play an important role in protecting rights, compensating for injuries, implementing the rule of law, and facilitating the peaceful and just resolution of disputes." ${ }^{74}$ Further, in requiring the accessed court be impartial, access to justice demands that judges are not influenced in their judgments by personal biases or prejudices. ${ }^{75}$ As a necessary corollary, the re-

tims' Rights in International Sentencing, 13 Soc. \& LeGist Srud. 27, 48-49 (2004) (conceptualizing of access to justice in terms of the mechanisms and procedures of a criminal trial that balance the concerns and interests of the accused, victims, prosecutors, judges, and the community at large).

73. E.g., Organization of African Unity, African (Banjul) Charter on Human and Peoples' Rights, art. 7(1)(d), June 27, 1981 (Every person has a "right to be tried within a reasonable time by an impartial court or tribunal."); Organization of American States ("OAS"), American Convention on Human Rights, art. 8(1), Nov. 22, 1969 [hereinafter "American Convention"] ("Every person has the right to a hearing, with due guarantees and within a reasonable time, by a competent, independent, and impartial tribunal, previously established by law, in the substantiation of any accusation of a criminal nature made against him ...."); International Covenant on Civil and Political Rights, art. 14(1), opened for signature Dec. 16, 1966 [hereinafter "ICCPR"] ("In the determination of any criminal charge against him, or of his rights and obligations in a suit at law, everyone shall be entitled to a fair and public hearing by a competent, independent and impartial tribunal established by law."); Council of Europe, Convention for the Protection of Human Rights and Fundamental Freedoms, art. 6(1), opened for signature Nov. 4, 1950 [hereinafter "European Convention of Human Rights" or "ECHR"] ("In the determination ... of any criminal charge against him, everyone is entitled to a fair and public hearing within a reasonable time by an independent and impartial tribunal established by law."); UDHR, supra note 62, at art. 10 ("Everyone is entitled in full equality to a fair and public hearing by an independent and impartial tribunal, in the determination of his rights and obligations and of any criminal charge against him."); OAS, American Declaration on the Rights and Duties of Man, art. 26, adopted May 2, 1948 [hereinafter "American Declaration"] ("Every person accused of an offense has the right to be given an impartial and public hearing, and to be tried by courts previously established in accordance with pre-existing laws ...."). Note that the United States is party to the American Convention, ICCPR, UDHR, and American Declaration and is consequently bound by these "structural access to justice" protections. The U.S. is also bound to the extent that this facet of access to justice may be a jus cogens norm. See supra note 61 and accompanying text.

74. Christopher A. Whytock, Foreign State Immunity and the Right to Court Access, 93 B.U. L. Rivv. 2033, 2048 (2013). See also Human Rights Comm., General Comment No. 32: Article 14: Right to Equality Before Courts and Tribunals and to a Fair Trial \$ 9, U.N. Doc. CCPR/C/ GC/32 (July 27, 2007) [hereinafter "General Comment No. 32"] (The right to a competent, independent and impart tribunal in Article 14 of the ICCPR "encompasses the right of access to the courts in cases of determination of criminal charges and rights and obligations in a suit at law.").

75. See General Comment No. 32, supra note 74, at 10 21; see also Steven Malby, The Rule of Law and Sustainable Development, 43 Commonwı:ALti L. Bul.. 521, 523 (2017) (defining access to justice, in part, as equality before the law and the legal empowerment of all individuals 
quirement of equal access to a tribunal necessarily requires that such biases or prejudices also not operate as a bar to adjudication in the first instance. ${ }^{76}$ And, finally, competency requires that the adjudicatory tribunal be constituted by law with the authority to hear the matter before it. ${ }^{77}$ Note, however, that the structural component of access to justice does not require that the "public hearing" before the impartial tribunal necessarily take the form of a trial; trial substitutes like plea bargaining are fully permissible so long as they comply with the other requirements of access to justice, such as tribunal impartiality and procedural guarantees. ${ }^{78}$

Most human rights instruments, including those to which the U.S. is a party, also contain commensurate provisions entitling all criminal defendants to certain procedural guarantees, including a right to be presumed innocent; a right to be informed of charges against them; a right to an adequate defense, including a right to assistance of counsel to prepare such defense; a right against being compelled or coerced to plead guilty; and a right to be tried without undue delay. ${ }^{79}$ Arguably

subject to legal process to effectively use the system to advance their rights through participation in the decision-making process).

76. General Comment No. 32, supra note 74, at 98.

77. See id. ๆष 16-18, 24.

78. See, e.g., Ralph Henham, Procedural Justice and Human Rights in International Sentencing, 4 INT'L CRIM. L. REv. 185, 186-90 (2004) (describing procedural protections necessary to ensure human rights compliance for plea bargains in international criminal proceedings).

79. Organization of African Unity, supra note 73, at art. 7(1)(b)-(d) ("Every individual shall have ... the right to be presumed innocent until proved guilty by a competent court or tribunal"; "the right to defence, including the right to be defended by counsel of his choice"; and "the right to be tried within a reasonable time."); American Convention, supra note 73, at art. 8(2) ("Every person accused of a criminal offense has the right to be presumed innocent so long as his guilt has not been proven according to law. During the proceedings, every person is entitled, with full equality, to ... minimum guarantees," which include "prior notification in detail to the accused of the charges against him," the right to an adequate defense and assistance of counsel to prepare such defense, the right to examine witnesses, and "the right not to be compelled to be a witness against himself or to plead guilty."), art. 8(3) ("A confession of guilt by the accused shall be valid only if it is made without coercion of any kind."); ICCPR, supra note 73, at art. 14(2) ("Everyone charged with a criminal offence shall have the right to be presumed innocent until proved guilty according to law."), art. 14(3) ("In the determination of any criminal charge against him, everyone shall be entitled to ... minimum guarantees, in full equality," which include the right to be informed of charges against him, the right to an adequate defense and counsel, the right to "be tried without undue delay," the right to examine witnesses against him, and the right "[n]ot to be compelled to testify against himself or to confess guilt."); ECHR, supra note 73, art. 6(2) ("Everyone charged with a criminal offence shall be presumed innocent until proved guilty according to law."), art. 6(3) ("Everyone charged with a criminal offence has ... minimum rights," which include the right to be informed of the charges against him, the right to a defense and to counsel to prepare such defense, and the right to examine witnesses against him); UDHR, supra note 67, art. 11(1) ("Everyone charged with a penal offence has the right to be presumed innocent until proved guilty according to law in a public trial at which he has had all the guarantees necessary for his defence."); American Declaration, supra note 73, art. 26 
the most fundamental of these provisions is the presumption of innocence and, as a necessary corollary, the allocation of the burden of proof to the prosecution to prove the defendant's guilt, rather than to the defendant to prove their innocence. ${ }^{80}$ Further, defendants must be treated in accordance with such presumption, meaning that, for instance, neither the fact of pretrial detention nor its length should be taken as an indication of guilt. ${ }^{81}$ Thus, to the extent that a jurisdiction's trial practices-or trial substitutes, such as plea bargainingerode these procedural guarantees, they undermine access to justice. ${ }^{82}$

\section{Bail Undermines Access to Justice}

Following arrest, defendants are brought before a judge or magistrate to determine whether they will be released pending disposition of the criminal charges against them, and on what conditions and what price bail, or whether they will be detained pretrial. ${ }^{83}$ These bail hearings can occur simultaneously to arraignments-the proceeding in which charges are formally filed and the first opportunity for a defendant to submit a plea-or months prior to arraignment, depending on the jurisdiction. ${ }^{84}$ Many jurisdictions hold bail hearings by video conference. ${ }^{85}$ Defendants are rarely represented by counsel at such hearings. ${ }^{86}$ At a bail hearing, a judge may release the defendant on their own recognizance (meaning the defendant is released without any conditions save an order to appear at a later date); release the defendant on nonmonetary conditions, such as pretrial supervision, curfews, or electronic monitoring; set a monetary bail amount, payment of

("Every accused person is presumed to be innocent until proved guilty."). Note that the United State is party to the American Convention, ICCPR, UDHR, and American Declaration and is consequently bound by these procedural access to justice protections. The U.S. is also bound to the extent that this facet of access to justice may be a jus cogens norm. See supra note 61 and accompanying text.

80. General Comment No. 32, supra note 74, II 30.

81. Id.

82. Findlay, supra note 72 , at $252-53$ (noting the equation of a defendant's full trial participation to their realization of access to justice).

83. Megan T. Stevenson, Distortion of Justice: How the Inability to Pay Bail Affects Case Outcomes, 34 J.L. Econ. \& ORG. 511, 514 (2018).

84. Id. at 514-15. In New York City, the bail hearing and arraignment occurs in the same proceeding; felony defendants in New Orleans are often arraigned as much as four months after their bail hearing; and Philadelphia defendants are typically arraigned within a month of their bail hearing. $I d$. at 515 .

85. E.g., Paul Heaton et al., The Downstream Consequences of Misdemeanor Pretrial Detention, 69 StAN. L. REv. 711, 720, 733 (2017) (noting that $57 \%$ of jurisdictions in 2009 held bail bearings over video conference).

86. Id. See also Stevenson, supra note 83 , at 514 n.5 (" $40 \%$ of respondent districts do not have defense attorneys at bail hearings." (internal citations omitted)). 
which will secure their release; or deny release altogether, mandating the defendant be held pending trial. ${ }^{87}$

Cash bail is a ubiquitous condition of release: for instance, for nonfelony defendants, bail is set in twenty-five percent of cases in New York City and in fifty percent of cases in Baltimore; 88 and, for felony defendants in New York City, bail is set in sixty-one percent of cases. ${ }^{89}$ If defendants for whom bail is set are unable to pay the full amount of their bail, they may still secure their release through use of a bail bondsman, to whom they pay a nonrefundable fraction of the bail amount (typically ten to fifteen percent) in return for the bondsman posting the remainder of the bail amount with the court..$^{90}$ So long as the defendant does not commit a new crime or fail to appear at trial, the defendant will not be liable for the bail (less any amount paid a bondsman). ${ }^{91}$ But if defendants are unable to post the bail--or pay the fraction required for a bondsman to post the bail-they will be denied release and jailed until the resolution of their charges. ${ }^{92}$

Bail is meant to serve two fundamental goals: (1) ensuring a defendant's appearance at trial and (2) mitigating public safety concerns that would result if the defendant committed a new crime while released pretrial. ${ }^{93}$ Further, because pretrial detention implicates the fundamental right to liberty, ${ }^{94}$ the United States Constitution requires the conditions set on a defendant's release-including bail-to be "narrowly focuse[d]" on these purposes 95 based on individualized as-

87. Arpit Gupta et al., The Heavy Costs of High Bail: Evidence from Judge Randomization, 45 J. LEGAL STUd. 471, 476-77 (2016).

88. Natapoff, supra note 39 , at 1321-22.

89. SUBRAMANiAn ET AL.., supra note 37 , at 29.

90 . Stevenson, supra note 83 , at 514. Among 2009 felony cases, private surety bonds accounted for four of every five pretrial releases on bail. SUBRAMANIAN ET AL., supra note 37, at 29. In some jurisdictions, such as Philadelphia, the court may act as a bondsman, releasing the defendant after payment of a deposit. Stevenson, supra note 83, at 514.

91. Stevenson, supra note 83 , at 514 . If the defendant used a bail bondsman, they forfeit the amount paid to the bondsman but will not be liable for the remainder of the bail; if the defendant themselves posted the full bail amount with the court, it will be returned to them in its entirety. Id.

92. See id.

93. United States v. Salerno, 481 U.S. 739, 750-51 (1987) ("When the Government proves by clear and convincing evidence that an arrestee presents an identified and articulable threat to an individual or the community, we believe that, consistent with the Due Process Clause, a court may disable the arrestee from executing that threat."); Stack v. Boyle, 342 U.S. 1, 4 (1951) ("The right to release before trial is conditioned upon the accused's giving adequate assurance that he will stand trial and submit to sentence if found guilty.").

94. Salerno, 481 U.S. at 750, 755 (An individual has a "strong interest in liberty," and the Court will "not minimize the importance and fundamental nature of this right." Consequently, "[i]n our society liberty is the norm, and detention prior to trial or without trial is the carefully limited exception.").

95. Id. at 750 . 
sessments of the particular defendant and the charges against them. ${ }^{96}$ Nonetheless, too frequently, bail hearings last mere minutes, if not seconds, ${ }^{97}$ as judges automatically tick off bail amounts from a predetermined bail schedule that looks solely to the charged offense without ever inquiring into a defendant's ability to pay, ties to the community, mitigating factors, or other personal circumstances.98 Critics have therefore asserted that the process of moving defendants from arrest to bail to conviction is "a conveyor belt," 99 describing the misdemeanor system in particular as "assembly line justice."100

The remainder of this Part describes the ways in which the current procedures of bail fail to actualize bail's constitutional purposes and instead undermine criminal defendants' human right of access to justice. It looks first to who is detained pretrial, finding that the poor disproportionately comprise pretrial detainees because they are financially unable to post the cash bail that would purchase their release. Consequently, the negative externalities of pretrial detention redound almost exclusively to poor defendants and thereby create a tiered system of differential justice by income. Second, this Part looks to these aforementioned effects of pretrial detention on the criminal process, noting the ways in which bail-through pretrial detention and plea bargaining-distorts sentencing by disincentivizing defendants to fight for a trial and coercing defendants to accept guilty pleas merely to

96. See Stack, 342 U.S. at 5 ("Since the function of bail is limited, the fixing of bail for any individual defendant must be based upon standards relevant to the purpose of assuring the presence of that defendant. The traditional standards as expressed in the Federal Rules of Criminal Procedure are to be applied in each case to each defendant."). See also Bail Reform Act of 1966, 18 U.S.C. $\$ \$ 3146-52$ ("The purpose of this Act is to revise the practices relating to bail to assure that all persons, regardless of their financial status, shall not needlessly be detained pending their appearance to answer charges, to testify, or pending appeal, when detention serves neither the ends of justice nor the public interest.").

97. Stevenson, supra note 83, at $514 \mathrm{n.5}$ (internal citations omitted) (noting that bail hearings typically last only a minute or two in Philadelphia; three minutes in North Dakota; less than two minutes in Cook County, Texas; and only a couple of minutes in Harris County, Texas).

98. Pritrial. Just. Inst., Pri:trial. Justici: in Amlikica: A Survey or County Prittriat. Rizliasi: Pojicils, Prnctices and Outcomis 1-2, 7 (2010) (indicating 64\% of surveyed counties reported using a bail schedule, even though ABA best practices guidelines warn against use of bail schedules). See also Mustafa Z. Mirza, Dallas County's Secret Bail Machine, M^rsu^I. Proulcr (Sept. 4, 2018, 3:47 PM), https://www.themarshallproject.org/2018/09/04/dallas-countys-secret-bail-machine (describing the use of bail schedules in Dallas, Texas); Pinto, supra note 32 ("The sheer speed of the arraignment process makes it virtually impossible for the court to make informed decisions. Prosecutors have nothing to go on but a statement from the police and possibly a complaining witness, and defense lawyers know only what they've been able to glean from their brief interviews and perhaps a phone call or two. It's in this hurried moment, at the very outset of a criminal case, before evidence has been weighed or even gathered, that a defendant's freedom is decided.").

99. Stevenson, supra note 83 , at 518 .

100. Stevenson \& Mayson, supra note 53, at 768. 
avoid continued detentions. Thus, cash bail erodes defendants' human right of access to justice by manipulating the criminal process from an adjudication of factual and legal guilt or innocence to a conversation about wealth status.

\section{A. Jail for the Poor}

The vast majority of pretrial detainees are jailed solely for their inability to pay their bail, even when that bail is a few thousand dollars or less, ${ }^{101}$ meaning that although they could secure their release with only a few hundred dollars, they languish in jail. ${ }^{102}$ For instance, in a study of pretrial detainees in Philadelphia from 2006 to 2013, individuals for whom bail was set lower than $\$ 2,000$ (meaning they needed to post a bond of $\$ 200$ or less) were detained pretrial, on average, for 28 days, and $40 \%$ were detained for at least 4 days because they had not posted bail. ${ }^{103}$ For those with bail set at $\$ 5,000$ (a bond of $\$ 500$ ), nearly half were detained for at least 3 days for nonpayment of their bail. 104

Similarly, a study of New York City pretrial detention from 2009 to 2013 found that $71 \%$ of felony defendants and $68 \%$ of misdemeanants for whom bail was set were unable to post it and secure their release, ${ }^{105}$ even though, of those studied who were held on bail, $81 \%$ had bail set below $\$ 5,000$ and $44 \%$ had a less than $\$ 1,000$ bail. ${ }^{106}$ This follows a Human Rights Watch study in 2008 of nonfelony defendants in New York City that found only $13 \%$ of defendants with bail set at or below $\$ 1,000$ were able to post bail at arraignment. ${ }^{107}$ Further, of all nonfelony defendants for whom bail was set during the studied period, $27 \%$ were not able to make bail the day of their hearing but subsequently posted it; ${ }^{108}$ half of these defendants were still jailed for two to seven days and another quarter spent more than 15 days in jail

101. Heaton et al., supra note 85 , at 713 .

102. See supra notes 38-40, 101; see infra notes 103-13.

103. Stevenson, supra note 83 , at 520-23.

104. Id. at 523.

105. Leslie \& Pope, supra note 37, at 544-45.

106. Id. at 530 (internal citations omitted). For felony defendants, bail is set below $\$ 2,000$ in fifteen percent of cases and, for a majority, at less than $\$ 5,000$; for misdemeanor defendants, "well over half of individuals held on bail need less than $\$ 2,000$, and over a fourth need only a few hundred dollars" to secure their release. Id at 544-45.

107. Human Rights Watch, The Price of Freedom: Bail anid Pretrial Detention of Low Income Nonfelony Defindants in New York Crty 21 (2010), https:/www.hrw.org/ sites/default/files/reports/us1210webwcover_0.pdf. New York City is a jurisdiction in which bail hearings occur simultaneously with arraignments.

108. Id. at 22 . 
pretrial. ${ }^{109}$ An additional $48 \%$ of nonfelony defendants for whom bail was set in the studied period were never able to post bail and were consequently detained throughout the disposition of their case. ${ }^{110}$

Although these studies are typically unable to observe individual or household income (or otherwise measure socioeconomic status) to directly correlate wealth and pretrial detention, they presume thatgiven the evidence that a quarter of Americans cannot come up with $\$ 2,000$ in 30 days $^{111}$ - the relatively small bail amounts suggest that pretrial detainees, as a group, are "poor, with limited access to financial resources." 112 This conclusion is further bolstered by research such as a 2008 to 2013 study in Harris County, Texas that used zip codes as a proxy for wealth (due to the high degree of economic segregation in the county) and found only $30 \%$ of defendants from wealthy zip codes were detained pretrial, while $60-70 \%$ percent of defendants from poorer zip codes were detained. ${ }^{113}$

Additionally, these wealth-based disparities in pretrial detention are not explicable as functions of bail's public safety or flight risk purposes. For one, the above statistics show parallel wealth-based disparities in both felony and nonfelony cases, so the frequency of detention is not increasing solely in proportion to the gravity of the charged offense to support a public safety aim. Indeed, evidence suggests that bail amounts differ wildly among judges, meaning that whether and at how much bail is set is more a function of the particular judge's proclivities than of an individual defendant's characteristics or charged offense. ${ }^{114}$ This in itself contravenes the supposition that indi-

109. Id. at 23. The mean length of pretrial detention for New York City nonfelony defendants in the studied period who posted bail of less than $\$ 1,000$ at some time after arraignment was 15.7 days, and the median was five days. $I d$. Consequently, eighty-five percent of all nonfelony defendants were still detained a day after their arraignment, sixty-four percent were still incarcerated four days afterwards, forty-three percent five days after, twenty-five percent eighteen days after, and ten percent fifty days after. $I d$.

110. Id. at 22 .

111. Gupta et al., supra note 87 , at 498 (internal citations omitted).

112. Leslie \& Pope, supra note 37 , at 545.

113. Heaton et al., supra note 85 , at 737,743 .

114. Gupta et al., supra note 87, at 497-98. See also Anna Maria Barry-Jester, You've Been Arrested. Will You Get Bail? Can You Pay It? It May All Depend On Your Judge., FIVETIIIRTYEIGIr (June 19, 2018), https:/fivethirtyeight.com/features/youve-been-arrested-willyou-get-bail-can-you-pay-it-it-may-all-depend-on-your-judge/ ("In New York City, when clients of The Legal Aid Society who were charged with a misdemeanor in 2017 entered their initial arraignment, they had anywhere between a 2 and 26 percent chance of the judge setting a cash bail, depending on which judge was randomly assigned to oversee the court that day. For felonies, the range was even wider: anywhere between 30 and 69 percent. Those not assigned bail are likely to be released without having to pay, which means getting arrested on the wrong day can have a major consequence: You are more than twice as likely to have to pay your way to freedom. Can't find the money? You're stuck in jail."). 
viduals held on bail are detained because their release would threaten the public. Secondly, research suggests that defendants released pretrial who fail to appear for subsequent court dates rarely do so because they had fled the jurisdiction; it is more typically due to scheduling errors, meaning holding defendants on bail is hardly necessary to ensure appearance at trial, and bail is rarely calculated solely to prevent flight. ${ }^{115}$ This is borne out by the appearance rates of defendants who would have been held pretrial for their inability to pay but for support from a bail fund. The Bronx Freedom Fund, the oldest bail fund in New York City, for instance, saw $96 \%$ of its clients make it to each of their court appearances-"a return rate higher even than that of [defendants] who posted their own bail."116 In other words, the current procedures of bail do not serve either of its purported purposes: bail neither (1) operates as a means of protecting the public from defendants reoffending on release, nor (2) is it a necessary deterrent for failures to appear.

Furthermore, this phenomenon exists despite a long history of American jurisprudence maintaining that " $t \mathrm{t}]$ here can be no equal justice where the kind of trial a man gets depends on the amount of money he has." 117 The Supreme Court has pronounced it is "repugnant to the Constitution"118 to "punish[] a person for his poverty"1.19 or deny defendants access to criminal process due to their inability to

115. John Logan Koepke \& David G. Robinson, Danger Ahead: Risk Assessment and the Future of Bail Reform, 93 WASH. L. REv. 1725, 1765 (2018) ("[W]hen released defendants miss a court appearance, it is often not because they are fleeing from prosecution but, rather, for other reasons ranging from genuine lack of knowledge about the scheduled date to forgetfulness. What causes such non-flight failures to appear? . . People with jobs that have inflexible hours, or that require a significant commute, might find it difficult or impractical to miss work for a court date. A defendant might also fail to appear because they simply forget about an upcoming court appearance. They may be afraid or have insufficient information about how to get to court, what to do once there, and what will happen next." (internal citations and quotation marks omitted)). See also Human Rights WAtch, supra note 101, at 50-51 ("In New York City, 84 percent of criminal defendants who are not in pretrial detention attend all their scheduled court proceedings. Sixteen percent miss an appearance, but most of those return to court voluntarily within 30 days.").

116. Pinto, supra note 32.

117. Griffin v. Illinois, 351 U.S. 12, 19 (1956); accord Mayer v. City of Chicago, 404 U.S. 189, 196 (1971) ("The size of defendant's pocketbook bears no more relationship to his guilt or innocence in a nonfelony than in a felony case.").

118. Roberts v. LaVallee, 389 U.S. 40, 42 (1967).

119. Bearden v. Georgia, 461 U.S. 660,671 (1983) (recognizing that a state cannot revoke probation due to defendant's inability to pay a fine or restitution); accord Tate v. Short, 401 U.S. 395,399 (1971) (stating that a state cannot imprison defendant for "fine-only" offense because defendant cannot pay fine); Williams v. Illinois, 399 U.S. 235, 242 (1970) (finding that a state cannot incarcerate defendant beyond statutory maximum solely for inability to pay accompanying legal fine). 
pay an often nominal fine. ${ }^{120}$ Lower courts have consequently decried the current state of cash bail and pretrial detention, noting that "access to wealth is what often determines whether a defendant is freed or must stay in jail," and the slow-moving nature of reforms in rectifying these issues is "a threat to equal justice under the law."121

But these declarations are platitudes without teeth. Despite these purported jurisprudential ideals, the incarceration of poor defendants for inability to pay their bail exists within the larger structure of "criminal justice debt"-by which fines and fees are imposed as a purportedly non-punitive alternative to incarceration but nonetheless result in the carceral punishment of poor defendants ${ }^{122}$ - and cash bail must be understood in this broader context. Some have argued that

120. E.g., Mayer, 404 U.S. at 190 (cannot deny defendants an adequate record to appeal a conviction due to inability to pay); Roberts, 389 U.S. at 42 (cannot deny defendants a transcript of preliminary hearing for use at trial due to inability to pay); Douglas v. California, 372 U.S. 353, 354 (1963) (cannot deny defendants counsel on first appeal as a matter of right due to inability to pay); Smith v. Bennett, 365 U.S. 708, 708 (1961) (cannot deny defendants an application for a writ of habeas corpus due to inability to pay); Burns v. Ohio, 360 U.S. 252, 253 (1959) (cannot deny defendants a motion for leave to appeal due to inability to pay); Griffin, 351 U.S. at 13 (cannot deny defendants transcript of trial proceedings for purposes of appeal due to inability to pay). Note, however, that the Court has always treated inability to pay as a distinct factual matter from refusal to pay. E.g., Bearden, 461 U.S. at 668-69 (drawing a distinction between "a probationer's failure to make sufficient bona fide efforts to seek employment or borrow money in order to pay the fine or restitution," which "may reflect an insufficient concern for paying the debt he owes to society for his crime," and a probationer who "has made all reasonable efforts to pay the fine or restitution, and yet cannot do so through no fault of his own," where revocation of probation and incarceration of the is permissible for the former, but not for the latter); Tate, 401 U.S. at 400 ("We emphasize that our holding today does not suggest any constitutional infirmity in imprisonment of a defendant with the means to pay a fine who refuses or neglects to do so.").

121. E.g., Curry v. Yachera, 835 F.3d 373, 377 (3d Cir. 2016) (highlighting that under the current bail system, "individuals posing little flight or public safety risk . . . are detained in jail [solely] because they cannot afford the bail set for criminal charges that are often minor in nature"). Judges' hands remain tied by the limited legal questions immediately before them, however. Id. (dismissing Plaintiff's malicious prosecution claim because his nolo contendere plea, tendered because he was unable to post bail and needed to return home, "operate[d] as a procedural bar" to "his ability to seek redress for the potentially unconstitutional prosecution that landed him in jail in the first place"); see also supra note 34 and accompanying text. Additionally, courts are bound by Supreme Court precedent that the right to bail is not absolute and may constitutionally be denied to "ensure the integrity of the judicial process" (although the Eighth Amendment does require that bail not be excessive when granted). United States v. Salerno, 481 U.S. 739, 753-54 (1987).

122. Laura I. Appleman, Nickel and Dimed into Incarceration: Cash-Register Iustice in the Criminal System, 57 B.C.L. Rzv. 1483, 1526 (2016). For instance, Appleman gives the example of a three hundred dollar fine imposed as an alternative to imprisonment: while this may "signify a minimal punishment-a slap on the wrist-to the average middle-class offender, this same fine would loom large for the poor or indigent offender ..." Id. Additionally, criminal justice debt rarely comes as an isolated incident; it is typically accrued in small increments-straws which break the proverbial camel's back in a steady and unabated accumulation of periodic "minor" fines and fees over an extended period. Id. at 1487. 
this system of "cash register justice" is an unconstitutional ${ }^{123}$ departure from the Supreme Court's equal justice precedents, ${ }^{124}$ but criminal justice debt still thrives. Its continued survival is due in no small part to the use of legal fines, fees, and bonds as a means of revenue generation to fill gaps in shrinking local budgets. ${ }^{125}$ Nowhere is this more apparent than municipalities like Baltimore, Maryland and Ferguson, Missouri, where the Department of Justice ("DOJ") found that police use legal fines and fees from misdemeanor arrests and punishments to "generate revenue on the backs of the poor." 126

In Ferguson, for instance, the DOJ found police officers "aggressive[ly] enforce[d]" the municipal code ${ }^{127}$-sometimes unconstitutionally128_-without regard for whether such "enforcement strategies promote public safety or unnecessarily undermine community trust and cooperation." 129 In turn, the Ferguson municipal court-rather than "act[ing] as a neutral arbiter of the law or a check on unlawful police conduct"- "primarily use[d] its judicial authority as the means to compel the payment of fines and fees that advance the City's financial interests," including regularly issuing arrest warrants for missed fine payments. ${ }^{130}$ And, it imposed these fines and fees without offer-

123. See generally id. at $1485-87$.

124. See supra notes $117-21$ and accompanying text.

125. Wayne A. Logan \& Ronald F. Wright, Mercenary Criminal Justice, 2014 U. ILL. L. REv. $1175,1212-15$ (2014) (arguing legal financial obligations distort criminal justice actors' incentives from a justice goal to a revenue generation goal through the use of "self-dealing" to supplement local criminal justice budget gaps); see also Appleman, supra note 122, at 1540 ("Rising expense in the criminal justice system and shrinking public budgets have resulted in a cost transfer from state and county courts to those arrested, indicted, and convicted, imposing a heavy burden of criminal justice debt on a largely indigent population.").

126. Stevenson \& Mayson, supra note 53, at 736.

127. Department of Justice, investigation of the Ferguson Police Department, supra note 47 , at 2 .

128. Id. at 2-3. ("This culture within [the Ferguson Police Department] influences officer activities in all areas of policing, beyond just ticketing. Officers expect and demand compliance even when they lack legal authority. They are inclined to interpret the exercise of free-speech rights as unlawful disobedience, innocent movements as physical threats, indications of mental or physical illness as belligerence. Police supervisors and leadership do too little to ensure that officers act in accordance with law and policy, and rarely respond meaningfully to civilian complaints of officer misconduct. The result is a pattern of stops without reasonable suspicion and arrests without probable cause in violation of the Fourth Amendment; infringement on free expression, as well as retaliation for protected expression, in violation of the First Amendment; and excessive force in violation of the Fourth Amendment.").

129. Id. at 2 .

130. Id. at 3. Defendants are not typically jailed for their failure to pay the fine; rather, the failure to pay is converted into a failure to appear-an offense more easily eligible for carceral punishment - when the defendant does not appear in court to explain why they are unable to pay their fine. Thomas Harvey et al., ArchCity Defindders, Municipal. Courts White PAPER 8-9 (2014), https://www.archcitydefenders.org/wp-content/uploads/2019/03/ArchCity-Defenders-Municipal-Courts-Whitepaper.pdf. Missed appearances are often due to insufficient 
ing adequate opportunity for defendants "to seek a fine reduction on account of financial incapacity or to seek alternatives to payment such as community service"-meaning, for Ferguson residents living at or near poverty, "[m]inor offenses can generate crippling debts [and] result in jail time because of an inability to pay."131 Further, to then secure release from their detention on the arrest warrant stemming from their failure to pay, defendants are made to pay a bond directly to the municipality - but when defendants had already been incarcerated due to their inability to pay a fine, they remained equally unable to pay their bail bond and secure their release, resulting in prolonged detentions. ${ }^{132}$ The DOJ attributed these police and court practices primarily to a goal of revenue generation, noting that Ferguson made approximately $\$ 2$ million in revenue annually from 2012 to 2014 solely from court fines, fees, and bonds and projected over $\$ 3$ million in revenue in 2015 for the same ${ }^{133}$ - an especially gruesome statistic when nearly a quarter of Ferguson residents live below the federal poverty line. ${ }^{134}$ In other words, Ferguson residents were detained pretrial on noncriminal municipal charges-that neither created a public safety threat nor suggested a risk they would abscond-for the sole purpose

transparency of court procedure regarding defendants' rights and responsibilities. DI:PARTMI:N'

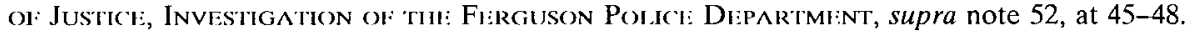

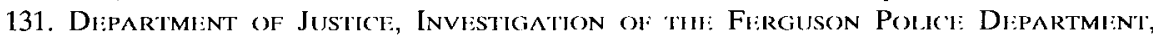
supra note 52 , at 3-4. The DOJ recounted, for instance, the story of one African-American woman whose case was still pending from her one instance of parking her car illegally:

She received two citations and a $\$ 151$ fine, plus fees. The woman, who experienced financial difficulties and periods of homelessness over several years, was charged with seven Failure to Appear offenses for missing court dates or fine payments on her parking tickets between 2007 and 2010. For each Failure to Appear, the court issued an arrest warrant and imposed new fines and fees. From 2007 to 2014, the woman was arrested twice, spent six days in jail, and paid $\$ 550$ to the court for the events stemming from this single instance of illegal parking. Court records show that she twice attempted to make partial payments of $\$ 25$ and $\$ 50$, but the court returned those payments, refusing to accept anything less than payment in full. One of those payments was later accepted, but only after the court's letter rejecting payment by money order was returned as undeliverable. This woman is now making regular payments on the fine. As of December 2014 , over seven years later, despite initially owing a $\$ 151$ fine and having alId at 4 . ready paid $\$ 550$, she still owed $\$ 541$.

132. Id. at $59-62$.

133. Id. at 2, 9-15. It is not immediately apparent the extent to which bonds independently generated revenue for Ferguson, as opposed to in concert with fines and fees; rather, bonds acted as a means of attempting to secure at least a fraction of the fines and fees debt by using the lever of release from incarceration to compel the requisite payment. The sum result perpetuated a system of "cash register justice" by forcing poor defendants to pay the municipality to secure their release from jail in order to prop up the local budget.

134. Ferguson city, Missouri, QuickFac:s, U.S. Clinsus Burlinu, https:/www.census.gov/ quickfacts/fact/table/fergusoncitymissouri/IPE120219\#IPE120219 (last visited Dec. 30, 2020). The median household income in Ferguson between 2015 and 2019 was $\$ 40,000$. Id. 
of collecting bond and fine money and thereby generating municipal revenue. Thus, evidence suggests defendants detained pretrial are incarcerated due to their poverty, rather than due to flight or public safety concerns; and existing Supreme Court jurisprudence-although theoretically promising a system of equal justice regardless of wealth status-in fact permits not only pretrial detention of the poor on cash bail, but also allows this larger system of "cash register justice" to flourish, all of which disproportionately penalizes the poor. ${ }^{135}$

\section{B. And Justice for the Rich}

Pretrial detention is indisputably linked to adverse case outcomes. ${ }^{136}$ Firstly, pretrial detainees are significantly more likely to be convicted than released defendants. ${ }^{137}$ For instance, a review of nonfelony cases in New York City in 2003 and 2004 found that defendants held on bail pretrial were convicted in $92 \%$ of cases, while defendants who were never detained pretrial were convicted only $50 \%$ of the time. ${ }^{138}$ The Bronx Freedom Fund reported that-while half of its clients from 2007 to 2009 saw their charges completely dismissed once they were released, and none of its clients went to jail on the charges for which bail had been posted- $-92 \%$ of defendants held on bail through the disposition of their cases were convicted. ${ }^{139}$ A Philadelphia study from 2006 to 2013 concluded that pretrial detainees are "7.6 percentage points more likely to receive a sentence of incarceration over a mean of $16 \%$ incarceration rate." 140 A study of Philadelphia from 2007 to 2014 and Miami-Dade County from 2006 to 2014 found that pretrial release decreases the likelihood of conviction by $24.2 \%$-as compared to the mean for detained defendants-largely due

135. See supra notes 111-18, 117-23, 125 and accompanying text.

136. Empirical literature is inconclusive whether the link is causal or merely correlational, but the correlation between pretrial detention and both the likelihood of conviction and sentence length is unambiguous. Heaton et al., supra note 79, at 714, 724-29. Part of the struggle in finding causation is that pretrial detention and criminal sentencing is a vicious cycle; if detention increases the likelihood and severity of criminal sentencing, then-if defendants are again arrested and charged - they are only more likely to be detained pretrial due to their criminal history and thereby only more likely to suffer the same adverse sentencing harms again. Id. at 736; Leslie \& Pope, supra note 37, at 548. Additionally, studies cannot control for factual innocence or guilt. Heaton et al., supra note 79, at 736. See also 2007 N.Y.C. Crim. Just. AgenCY, Pretrial Detention and Case Outcomes, Part 1: Nonfelony Cases 2-7 (2007) (summarizing past bail research). However, recent empirical literature suggests the link may indeed be causal. Samuel R. Wiseman, Bail and Mass Incarceration, 53 GA. L. Rev. 235, 245-47 (2018).

137. See infra notes 138-44 and accompanying text.

138. New York City Criminal Justice Agency, supra note 136, at 56.

139. Pinto, supra note 32.

140. Stevenson, supra note 83 , at 536 . 
to a decrease in guilty pleas. ${ }^{141} \mathrm{~A}$ study of Harris County misdemeanants $^{142}$ from 2008 to 2013 noted that while $55.7 \%$ of all released defendants were found guilty, that rate increased to $79.4 \%$ among pretrial detainees, with guilty pleas accounting for almost all convictions. ${ }^{143}$ And a study of felony defendants in New York City from 2009 to 2013 found pretrial detention increased the probability of conviction by $13 \% .{ }^{144}$

Further, once convicted, pretrial detainees' sentences are often harsher than those of their released counterparts. The New York City nonfelony study found, even when controlling for a dozen case and defendant characteristics in a multivariate analysis, bail was the strongest predictor of detention length, with $84 \%$ of defendants detained until disposition on bail subject to incarceration but only $10 \%$ of released defendants incarcerated. ${ }^{145}$ The Harris County misdemeanant study also revealed that while only $40.2 \%$ of those released received a jail sentence from their convictions, $75 \%$ of pretrial detainees were subject to a jail sentence; and detainees' sentences were, on average, nearly four times longer than that of released defendants. ${ }^{146}$ The Philadelphia study concluded pretrial detention led to an expected increase of 124 days in maximum days incarcerated -a $42 \%$ increase over the mean-and an increase in 136 days in the minimum time before parole eligibility. ${ }^{147} \mathrm{~A}$ one year study of Kentucky jails from 2009 to 2010 determined that, even after controlling for other factors, defendants detained for the entire pretrial period were 4.44 times more likely to be sentenced to jail than defendants released at some point prior to trial. ${ }^{148}$ Those defendants detained through dispo-

141. Dobbie et al., supra note 36 , at 203.

142. It is worth noting that while misdemeanor convictions may sound as if they are "trivial," misdemeanants are subject to "jail time, heavy fines, [and] invasive probation requirements," much like felony defendants. Heaton et al., supra note 85, at 714-15. And misdemeanants also face similar collateral consequences such as potential deportation; loss of child custody; barriers to finding employment and housing; social stigmatization; disenfranchisement; diminished social and educational opportunities; lessened or no access to professional licenses; ineligibility for food stamps and other government benefits; and ballooning legal fines, costs, and other economic penalties. Id.; Natapoff, supra note 39, at 1316-17, 1325-27.

143. Heaton et al., supra note 85 , at $736.52 .8 \%$ of released misdemeanants pleaded guilty, as compared to $76.8 \%$ of pretrial detainees. $I d$.

144. Leslie \& Pope, supra note 37, at 530.

145. Niz York City Criminat. Justice Agincy, supra note 135, at 56.

146. Heaton et al., supra note 85 , at 736 . Jail sentences averaged to be 25.4 days for detainees and 7.4 days for released defendants. $I d$.

147. Stevenson, supra note 83, at 534-35.

148. Cilristophi:r T. Lowenkamp it al., Invistignting tile Impact of Preitrial. Deti:nTION ON SI:NTINANCING OUTCOMES 10 (2013). Those held until disposition were also 3.32 times more likely to be sentenced to prison than those released. $I d$. 
sition had a jail sentence 2.78 times longer than those released. ${ }^{149}$ And the 2009 to 2013 New York City study determined individuals charged with felonies were $10 \%$ less likely to receive a reduction in charge class if detained, versus if released, so that they were more likely to be convicted of a serious crime and see an analogously more severe punishment. ${ }^{150}$

This all necessitates asking why pretrial detainees are more likely to be convicted and subjected to harsher sentences. One of the most commonly cited mechanisms is that detention alters the incentives for contesting a charge. ${ }^{151}$ Especially in the context of misdemeanors, pretrial detainees are uniquely susceptible to the pressures of plea bargaining-regardless of their factual or legal innocence ${ }^{152}$-because they are routinely offered sentences for "time served" or probation in exchange for the guilty plea. ${ }^{153}$ In other words, pleas-in exchange for what appears to be a "seemingly trivial sentence"-present an immediate opportunity for release. ${ }^{154}$ And the incentives for release only grow more compelling in light of the potential disruptions to their lives that continued imprisonment would cause detainees through, for instance, lack of child care, loss of employment, lost wages, lack of access to substance abuse or mental health treatment programs, loss of housing, etc. ${ }^{155}$ And, it is also worth remembering that jail is hardly a pleasant place to be: jails are often overcrowded and chaotic; abusive, sometimes to the point of fatality; disease and infection-ridden with minimal physical or mental health services available; unsafe due to mold, poor ventilation, asbestos, and/or lead pipes; and with inadequate sleeping arrangements or meals. ${ }^{156}$ Additionally, whereas for re-

149. Id. Prison sentences for continued detainees is 2.36 times longer than for those released. Id.

150. Leslie \& Pope, supra note 37, at 548.

151. See infra notes $152-60$ and accompanying text.

152. Natapoff, supra note 39 , at 1346-47; see also Human RigHrs WATCH, supra note 107 , at 31-33 ("Defense attorneys believe prosecutors ask for bail, including in cases they know are likely to be dismissed ... simply to get pleas from defendants who will not want to languish in pretrial detention" because their bargaining position is weaker when their primary goal is to get out of jail as soon as possible, rather than to contest their innocence.).

153. Heaton et al., supra note 85 , at 715.

154. Id.

155. Human Rights Watch, supra note 107, at 2; New York Crty Criminal. Justice AGENCY, supra note 136, at 59; Heaton et al., supra note 85 , at 713-14; Stevenson, supra note 83 , at 512. See also supra notes 1-34 and accompanying text (discussing disruptive harms of pretrial detention).

156. Laura I. Appleman, Justice in the Shadowlands: Pretrial Detention, Punishment, \& the Sixth Amendment, 69 WASH. \& LEF L. REv. 1297, 1301-02, 1315, 1318-19 (2012). See also supra notes 1-31 (describing the experiences of Kalief Browder, Sandra Bland, Janice Dotson-Stephens, and Layleen Cubilette-Polanco when jailed pretrial). 
leased defendants even "trivial sentences" may impose a new loss of liberty (incentivizing them to fight their charges); for pretrial detainees, even a custodial sentence is, at worse, an extension of the status quo (creating a perverse disincentive to fight their charges). ${ }^{157}$ This is especially the case for minor offenses (although it is not untrue for felony charges ${ }^{158}$ ) in which convictions rarely pose a threat of jail time unless the incarceration occurs as a form of pretrial detention-meaning, for these offenses, those held on bail serve a harsher punishment pretrial ${ }^{159}$ than they do from their actual conviction. ${ }^{160}$

A second mechanism linking pretrial detention to adverse case outcomes may be that detainees are less able to develop an adequate defense when jailed. Behind bars, defendants' capacity to find and work with an attorney or to collect evidence for their defense is limited. ${ }^{161}$ Further, where detention causes a loss of employment or wages, detainees may also have more limited financial resources to dedicate to their defense. ${ }^{162}$ And, especially in misdemeanor cases, the weakened or nonexistent assistance of counsel results in (as in the first mechanism), a no-longer meaningfully adversarial process that pushes

157. Heaton et al., supra note 85 , at 722 .

158. Leslie \& Pope, supra note 37, at 551-53.

159. Legally, pretrial detention is not punishment; that would violate the Due Process Clause. Bell v. Wolfish, 441 U.S. 520, 535 (1979). But practically, even the seminal Supreme Court decision declaring pretrial detention not a punishment found that "[w]hether it be called a jail, a prison, or a custodial center, the purpose of the facility is to detain. Loss of freedom of choice and privacy are inherent incidents of confinement in such a facility." Id. at 537. At its essence, incarceration is incarceration is incarceration; and the differences between imprisonment in a jail pretrial or in a jail or prison post-conviction fail to differ in any significantly meaningful way in

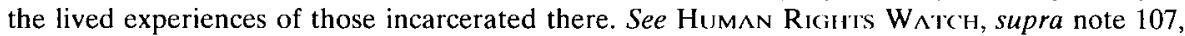
at 28 ("[F]or those who are in jail because they cannot post bail, the experience scarcely differs from being in jail because of a sentence of guilt."); Anna Roberts, Arrests as Guilt, 70 Al.A. L. Ri:v. 987, 999, 1025 (2019) (describing pretrial detention as pretrial "punishment"). Constitutionally, the distinction is of preeminent import, but practically, incarceration-whether pretrial or post-conviction-is accompanied by the same removal from daily life that creates the same pressures to clamor for release, the same subjection to the same squalid conditions and restrictive supervision, and the same personal shame and societal stigma. Sandra G. Mayson, Dangerous Defendants, 127 YAll: L.J. 490, 538, 545, 549-51 (2018). A rose by any other name would smell as sweet.

160. HuMAN Ricints WATC1, supra note 107 , at 30 ("The time in pretrial detention (as well as in police lockup pre-arraignment) is quite literally punishment paid in advance . . . The median length of pretrial incarceration for misdemeanor defendants arrested in 2008 [in New York City] is five days, the average is 15; yet according to the New York State Division of Criminal Justice Services, in 48 percent of cases in which people arrested on misdemeanor charges are convicted and sentenced to jail, the sentence is less than 15 days; in 9 percent of the cases, it is less than five days."). See also Natapoff, supra note 39, at 1322 ("Indeed, many arrestees plead guilty to petty offenses in exchange for a sentence of time served as a way of terminating what might otherwise be a longer period of incarceration than the offense carries.").

161. Heaton et al, supra note 85 , at 722 ; Stevenson, supra note 83 , at 512 .

162. Heaton et al., supra note 85 , at 722 . 
defendants towards guilty pleas-towards convictions-regardless of their factual and legal guilt or innocence. ${ }^{163}$

In either of these two mechanisms, the facility of and potential lack of procedural protections in plea bargains is an essential element. Guilty pleas, at their essence, serve as a "full substitute for a factual inquiry into guilt" on the principle that "a defendant who relinquishes his right to contest guilt must indeed be guilty." 164 But it is a legal fiction that all defendants who plead guilty do so because they are factually guilty ${ }^{165}$; defendants routinely accept guilty pleas for reasons other than their factual guilt. ${ }^{166}$ Indeed, the objection most commonly leveled against plea bargaining is that it diminishes procedural protections meant to avoid convictions of the innocent: plea bargaining neither "align[s] criminal consequences with actual guilt," 167 nor reflects expected trial outcomes. ${ }^{168}$ And while this Article is not meant to be an indictment of plea bargaining, it is necessary to understand the shortcomings of the plea system because bail and pretrial detention facilitate its most insidious facets by not only pushing defendants towards pleas, but shortening the time they have to decide whether to accept a plea. ${ }^{169}$ For instance, criminal guilt is meant to be proven

163. Stephanos Bibas, Plea Bargaining Outside the Shadow of Trial, 117 Harv. L. Rev. 2463, 2491 nn.108-09 (2004); Natapoff, supra note 39, at 1316; Stevenson \& Mayson, supra note 53, at $735-36$.

164. Natapoff, supra note 39, at 1345 (citing Brady v. United States, 397 U.S. 742, 748 (1970) ("Central to the plea and the foundation for entering judgment against the defendant is the defendant's admission in open court that he committed the acts charged in the indictment. He thus stands as a witness against himself ...")).

165. See Roberts, supra note 159, at 1013-14 (describing guilty pleas as merely "a formality that may make a mockery of a system that is often said to be interested in truth" because guilt is a foregone conclusion after arrest and stating that "our system of plea bargaining 'short-circuits' the process of determining guilt").

166. Gregory M. Gilchrist, Plea Bargains, Convictions, and Legitimacy, 48 AM. CRIM. L. REV. 143,146 (2011) (listing reasons why an innocent person may plead guilty).

167. Id. at 145,148 . Further, a recent survey of male Pennsylvania state prisoners asked to self-report factual innocence in non-capital cases found that " $22.2 \%( \pm 1.6)$ of inmates report committing some offenses related to their most recent conviction, and $11.1 \%( \pm 1.3)$ of inmates report committing none of the offenses in their most recent conviction." Charles E. Loeffler et al., Measuring Self-Reported Wrongful Convictions Among Prisoners, 35 J. Qunntitative CrimINOLOGY 259, 273 (2019). Based on this data, the researchers concluded "wrongful convictions occur in $6 \%$ of criminal convictions leading to imprisonment in an intake population of state prisoners." Id. at 259 . The researchers did not ask inmates whether their convictions were the product of a plea deal, but given the ubiquity of pleas in the criminal system, it is fair to infer a substantial number of the surveyed inmates pleaded guilty. See Roberts, supra note 159, at 1014.

168. Bibas, supra note 163 , at 2469-70.

169. Lindsey Devers, DOJ, Plea and Charge Bargaining: Research Summary 2 (2011), https://www.bja.gov/Publications/PleaBargainingResearchSummary.pdf; Gilchrist, supra note 166, at 157-58; Wiseman, supra note 136, at 241. See also Bibas, supra note 163, at 2493 ("Thus, pretrial detention places a high premium on quick plea bargains in small cases, even if the defendant would probably win acquittal at an eventual trial."). 
beyond a reasonable doubt precisely to avoid wrongful convictionseven if it comes at the expense of potential wrongful acquittals-but, where the need for a trial is obviated by a plea bargain, convictions can rest solely on the severely lesser standard of probable cause needed to initiate charges and then force concessions to reach sentencing. ${ }^{170}$ And, eschewing trials also means the Fourth Amendment exclusionary rule, the insanity defense, the right of confrontation, and the right of the press and public to observe criminal proceedings are also all rendered nonexistent. ${ }^{171}$ Secondly, by turning the adjudication of legal guilt into a negotiation of charges and sentences, plea bargaining substitutes a judicial determination of guilt or innocence with "a regime of split-the-difference" that commodifies and haggles over human liberty. ${ }^{172}$ This haggling also effectively merges prosecution, adjudication, and sentencing into "a single amorphous judgment" and consolidates the authority of judge, jury, and executioner into the sole entity of the prosecutor. ${ }^{173}$ The totality of these concerns means plea bargains "systematically circumvent[]" the presumption of innocence ${ }^{174}$-plea bargains, with the help of pretrial detention, fundamentally divorce criminal convictions from either factual or legal guilt.

And, once again, American jurisprudence has long conceded the deleterious distortion of bail and pretrial detention on criminal sentencing but been a far from efficacious tool to redress it. The Supreme Court has acknowledged imposing bail on an indigent defendant may mean that "[he is] denied freedom, where a wealthy man would not [be]." 175 And the Court has recognized that, when "lengthy pretrial incarceration" consequently results, the accused potentially faces job loss, disruptions in family life, and hindrances in their "ability to gather evidence, contact witnesses, or otherwise prepare [their] defense"176 - all of which may culminate in a wrongful conviction. ${ }^{177}$ Further, courts such as the Third Circuit have recognized that as a

170. Gilchrist, supra note 166, at 149--50, 153; John H. Langbein, Torture and Plea Bargaining, 46 U. Cill. L. Rev. 3, 12 (1978).

171. Albert W. Alschuler, Implementing the Criminal Defendant's Right to Trial: Alternatives to the Plea Bargaining System, 50 U. Cir. L. Ri:v. 931, 933-34 (1983).

172. Id. at 932.

173. Id. at 934; Langbein, supra note 170 , at 18 .

174. Gilchrist, supra note 166 , at 159 .

175. Bandy v. United States, 81 S. Ct. 197, 197-98 (1960).

176. Barker v. Wingo, 407 U.S. 514, 532-33 (1972); accord Gerstein v. Pugh, 420 U.S. 103, 114 (1975) ("Pretrial confinement may imperil the suspect's job, interrupt his source of income, and impair his family relationships."); Bandy, 81 S. Ct. at 198 ("Imprisoned, a man may have no opportunity to investigate his case, to cooperate with his counsel, to earn the money that is still necessary for the fullest use of his right to appeal.").

177. See Bandy, $81 \mathrm{~S}$. Ct. at 198 ("In case of reversal, [a pretrial detainee] will have served all or part of a sentence under an erroneous judgment."). 
result of these coercive collateral consequences, poor pretrial detainees unable to pay bail may be "forced to accept a plea deal to leave the jail environment and be freed," as they do not "have the 'luxury" of awaiting a trial on the merits of their charges." 178 As a result, the Supreme Court has held for over 65 years that bail and pretrial release are inextricably necessary to the presumption of innocence. ${ }^{179}$ Indeed, Justice Thurgood Marshall even stated that to detain a person pretrial on "allegations which are legally presumed to be untrue"-even if it is done on the theory that, purportedly, "the accused is likely to commit crimes"-is "consistent with ... tyranny and ... [a] police state" but is "incompatible with the fundamental human rights protected by our Constitution." 180

\section{A System of Jail for the Poor and Justice for the Rich Violates Human Rights}

The current cash bail system thus disproportionately detains the poor for their poverty - and not for their flight or public safety risksas part of a criminal system that too often operates as "cash register justice." Consequently, the negative externalities of pretrial detention-increased susceptibility to conceding guilt and decreased opportunities to defend innocence-redound primarily to the poor. For the poor, this tiered system of differential justice facilitates the most insidious aspects of plea bargaining (i.e., pushing defendants to concede guilt merely to terminate their pretrial jail sentence) and thereby produces adverse case outcomes and harshens sentences. Thus, in the aggregate, bail, through pretrial detention, encourages a system of convictions divorced from factual and legal innocence but intimately tied to wealth. And this system flourishes despite the Supreme Court having long recognized not only the systems' operation, but also its injustice.

Therefore, with the failure of American jurisprudence to resolve these inequities, advocates of effective bail reform must look to another tool to demand change: human rights. Namely, the human right of access to justice, which requires states provide all criminal defendants with access to a fair and impartial tribunal and afford them cer-

178. Curry v. Yachera, 835 F.3d 373, 376 (3d Cir. 2016).

179. See Stack v. Boyle, 342 U.S. 1, 4 (1951) ("Unless this right to bail before trial is preserved, the presumption of innocence, secured only after centuries of struggle, would lose its meaning.").

180. United States v. Salerno, 481 U.S. 739, 755 (1987) (Marshall, J., dissenting). 
tain procedural guarantees such as the presumption of innocenceboth components of which cash bail violates. ${ }^{181}$

The international community has already begun to recognize the correlation at least between pretrial detention and access to justice, insofar as the Sustainable Development Goals ("SDGs") reflect the aspirational public policy agenda of the international human rights community. ${ }^{182}$ SDG 16 - which aims to "[p]romote peaceful and inclusive societies for sustainable development, provide access to justice for all and build effective, accountable and inclusive institutions at all levels"-operationalizes the rule of law and access to justice in part by measuring the number of "[u]nsentenced detainees as a proportion of [the] overall prison population." 183 The U.N. notes that the link between pretrial detention and access to justice is borne of the right of a defendant awaiting trial not to be detained unnecessarily, which, in turn, is premised on the right to be presumed innocent until proven guilty, especially when pretrial detention is not predicated on preventing defendants from absconding or mitigating safety risks to victims, witnesses, or the public through recidivism. ${ }^{184}$

What is less internationally-recognized, however, as an obstacle to access to justice-and is the primary doctrinal contribution of this paper-is the predicate link in the American criminal system between bail and pretrial detention, which then exacerbates the access to justice issue. And this lack of attention is in large part because, in the words of Special Rapporteur on Extreme Poverty and Human Rights Philip Alston, it is a "distinctively American response to poverty" to

181. See supra Part I.

182. The SDGs were adopted by all U.N. Member States in 2015 as a "shared blueprint for peace and prosperity for people and the planet" through a global partnership. U.N. Di:P'T OF ECON. \& SoC. Alisirs, Sustainable Development Goals, https://sustainabledevelopment.un.org/ ?menu=1300 (last visited Oct. 21, 2019). There are seventeen SDGs-spanning from poverty eradication to increased access to health and education, from reduced inequalities to increased economic growth, and from preservation of the environment and climate action to promotion of just and equitable institutions-all to be completed by 2030. Id. Each SDG is measured by a set number of targets that build out the facets of the goal, and each target is then operationalized by indicators that measure states' performance over time in achieving the aims of the SDG. For instance, SDG 1 is to "[e]nd poverty in all its forms everywhere"; one of its targets (1.5) is to "[b]y 2030, build the resilience of the poor and those in vulnerable situations and reduce their exposure and vulnerability to climate-related extreme events and other economic, social and environmental shocks and disasters"; to then operationalize this target, indicator 1.5.1 looks to the "[n]umber of deaths, missing persons and persons affected by disaster per 100,000 people," and 1.5.3 examines the "[n]umber of countries with national and local disaster risk reduction strategies." U.N. Drip'r of Econ. \& Soc:. Alifarrs, Sustainable Development Goal 1, https:// sustainabledevelopment.un.org/sdg1 (last visited Oct. 21, 2019).

183. U.N. Disp't of Econ. \& Soc. Afrairs, Indicntor 16.3.2 Mi:Tadara 1 (2016), hatps:// unstats.un.org/sdgs/metadata/files/Metadata-16-03-02.pdf.

184. Id. 
use bail to "almost exclusively" detain the poor pretrial. ${ }^{185}$ Thus, this grotesquely unique facet of the American criminal system introduces the added complication of wealth-based disparities into the existing conversation on pretrial detention and access to justice. Accordingly, in the U.S. criminal system, bail violates the human right of access to justice. First, as to the structural component, it does so by producing systemic wealth-based biases in detention rates and case outcomes that violate the right to equal court access and may implicate the requirement of impartiality. Second, bail violates the procedural component of access to justice by transmuting convictions from a reflection of factual and legal guilt to a reflection of wealth and thereby extinguishing the most fundamental procedural guarantee-the presumption of innocence. The remainder of this section addresses each of these component violations in turn.

The structural component of access to justice requires all criminal defendants have equal access to a competent and impartial tribunal. ${ }^{186}$ This requires that the adjudicatory body which determines case outcomes (1) is constituted by law, (2) does not operate on the basis of biases or prejudices, and (3) is equally available to all defendants, without being inaccessible arbitrarily or on the basis of a defendant's identity status. ${ }^{187}$ The fact that bail and pretrial detention funnel defendants into a system of plea bargaining, rather than towards the trial structure constitutionally outlined, ${ }^{188}$ may call into question the competency of the adjudicatory tribunal, especially if one considers the prosecutor managing the plea the "tribunal" rather than the judge supervising the summary allocution. But, setting that aside for more definite concerns, bail creates even more acute access to justice complications regarding impartiality and equal access, both of which address the ability of all defendants to have their cases heard free of impediment, limit, or interference by institutional or individual biases. Namely, bail generates wealth-based disparities in pretrial detention, which in turn generates wealth-based disparities in case outcomes; and

185. Philip Alston (Special Rapporteur on Extreme Poverty and Human Rights), Report of the Special Rapporteur on extreme poverty and human rights on his mission to the United States of America, II 49-50, 71-72, U.N. Doc. A/HRC/38/33/Add.1 (May 4, 2018). See also Human Rights Council, Report of the Working Group on Arbitrary Detention on Its Visit to the United States of America, II 51, U.N. Doc. A/HRC/36/37/Add.2 (July 17, 2017) (describing lengthy pretrial detention due to excessively high bail amounts as the "criminalization of poverty").

186. See supra notes $72-73$ and accompanying text.

187. See supra notes $73-78$ and accompanying text.

188. This is not to say that pretrial detainees literally are not heard or are denied court access; instead, it is to recognize that the coercive pressures placed on poor defendants to plead guilty makes it nigh on impossible to fully actualize their structural and procedural access to justice rights. 
where wealth is the primary determinant of convictions, rather than factual or legal guilt, it necessarily signals that defendants' wealth statuses stand between them and their ability to have their cases heard without bias. ${ }^{189}$ Ergo, either or both defendants' rights to impartiality and equal access have been curtailed.

Secondly, the procedural component of access to justice mandates states guarantee all criminal defendants a presumption of innocence, an opportunity to prepare an adequate defense, and a trial without undue delay - the first of these being the most fundamental. ${ }^{190}$ Further, the presumption of innocence requires, as a necessary corollary, that the prosecution bear the burden of proving the defendant's guilt (rather than the defendant disproving it) and that the state may not use its machinery to compel or coerce a defendant to plead guilty. ${ }^{191}$ The U.S. Supreme Court and the international human rights community have already acknowledged that pretrial detention can erode the presumption of innocence because the sheer fact that a legally innocent individual is incarcerated symbolically represents a judgment on their dangerousness and their potential for criminality, which then inherently colors the subsequent stages of case disposition. ${ }^{192}$ And in the uniquely American criminal system, bail exacerbates this concern: bail, through pretrial detention, exerts a coercive influence on defendants to plead guilty so they may be released and, resultantly, shifts the burden of proof - both of which are access to justice violations. Recall that poor pretrial detainees routinely lose wages, employment, housing, child custody, and time with their families while jailed and that, when combined with the often deplorable conditions of jails, pretrial detainees feel a strong compulsion to secure their release any way they are able. When they are financially unable to secure their release by posting bail, they often turn to guilty pleas, especially when their detention also results in a commensurate difficulty accessing counsel or evidence to prepare their defense. ${ }^{193}$ Furthermore, plea bargaining, in practice, can lower the burden of proof required for a conviction from "beyond a reasonable doubt" to "probable cause" and erase

189. This is not to insinuate that the impartiality of the tribunal as to wealth-based justice disparities, rooted in bail, necessarily stems from the individual biases or prejudices of the judicial authority; lack of tribunal impartiality is as much a threat to access to justice when the judge, as the embodiment of the tribunal, is individually biased against the poor, as it is when the court itself, as an institution, is systematically biased against the poor. Either or both facets of tribunal impartiality-or lack thereof-may be implicated here to produce the access to justice concerns.

190. See supra notes $79-82$ and accompanying text.

191. See supra notes $79-80$ and accompanying text.

192. See supra notes $182,185-186$ and accompanying text.

193. See supra notes $32-34,152-163$ and accompanying text. 
constitutional rights (e.g., the Fourth Amendment exclusionary rule and the right of confrontation) while vesting near-exclusive decisional authority in the prosecutor haggling over how to split-the-difference as to the defendant's liberty. ${ }^{194}$ In effect, this creates a direct (potentially causal) link between bail and coerced guilty pleas. It also lessens the strength of the case the prosecution must present because the outcome-the guilty conviction necessary to secure release-is already presumably a foregone conclusion. ${ }^{195}$ When combined with the lowered burden of proof and the prosecutor's now-nearly-omnipotent authority, this operates, effectively, as a de facto burden shift whereby the prosecutor no longer has to prove guilt (because it is presumed) and any reductions in charges or sentencing must result from the strength of the defendant's evidence (rather than the weakness of the prosecutor's), even when the defendant's ability to marshal such evidence is already undermined by the insufficient opportunity to prepare an adequate and effective defense while detained pretrial on bail. All of the aforementioned - the coerced guilty plea, the burden shift, and the inadequate defense opportunity-violate the human right of access to justice independently and through their collective erosion of the presumption of innocence.

\section{Existing Bail Reforms are Not Enough to Access Justice: The Shortcomings of Algorithmic Pretrial Risk Assessment ToOls}

In an effort to decouple money from access to pretrial release, modern bail reform movements increasingly advocate to remodel the existing wealth-based system of cash bail into a risk-based system, ${ }^{196}$ which uses algorithmic pretrial risk assessment tools to predict whether a given defendant is likely to reoffend or subsequently fail to appear if released pretrial. ${ }^{197}$ These risk assessment tools typically use algorithms ${ }^{198}$ to conduct a regression analysis—or, more recently with

194. See supra notes 164-174 and accompanying text.

195. See supra note 152.

196. Aziz Z. Huq, Racial Equity in Algorithmic Criminal Justice, 68 Duk1 L.J. 1043, 1073 (2019); see also Megan Stevenson, Assessing Risk Assessment in Action, 103 Minn. L. Rev. 303, 304,317 (2018) (describing that the National Institute for Corrections has ranked risk assessment tools as "number one in a list of evidence-based ways to reduce recidivism" as part of a broad push to use big data, science, and new technology to be "smart-on-crime").

197. Stevenson, supra note 201, at 304.

198. "At their simplest, algorithms are formulas designed to calculate a particular result. Today, algorithms are typically understood as either a piece of code or a computer application that can be used to support human decision-making or to take actions independent of human input." Lorna McGregor et al., International Human Rights Law as a Framework for Algorithmic Accountability, 68 INT'L. \& COMP. L.Q. 309, 315 (2019). 
the increasing use of artificial intelligence, machine learning ${ }^{199}$ - to assess a defendant's "risk" level, using variables such as their age, gender, education, employment status, criminal record, marital status, and home neighborhood. ${ }^{200}$ Each factor is weighted according to the strength of its correlation with re-arrest or failure to appear based on historical criminal system data and then aggregated to create a total "risk" level for the defendant. 201

This revamped bail system is meant to serve two primary aims: (1) to more narrowly tailor pretrial detention programs to serve their twin constitutional aims (i.e., ensuring subsequent appearance and mitigating reoffense-related public safety risks) by detaining only those defendants purportedly empirically shown to pose a risk if released ${ }^{202}$ and (2) to rise above human bias by substituting a subjective human judge with an objective technology as the decisionmaker. ${ }^{203}$ In fact, it serves neither. Instead, it merely substitutes wealth-based disparities with race-based disparities-hardly an improvement in accessing justice.

The failure of algorithmic risk assessment tools is fundamentally reducible to four words: "bias in, bias out." 204 Prediction, by its very nature, "functions like a mirror": it presumes history will repeat itself and consequently extrapolates from patterns in past data and offers it as a mirror-image projection of the future. ${ }^{205}$ While this premise tantalizingly offers a "sheen of scientific credibility" to the otherwise

199. Sandra G. Mayson, Bias In, Bias Out, 128 YAl.I: L.J. 2218, 2228 (2019).

200. Stevenson, supra note 201, at 304, 315. See also Sonja B. Starr, Evidence-Based Sentencing and the Scientific Rationalization of Discrimination, 66 SinN. L. Ri:v. 803, 812-13 (2014) (describing the process and variables used in the Correctional Offender Management Profiling for Alternative Sanctions (COMPAS), a leading pretrial risk assessment tool).

201. Koepke \& Robinson, supra note 115, at 1752-53.

202. See Jennifer L. Skeem \& Christopher T. Lowenkamp, Risk, Race, and Recidivism: Predictive Bias and Disparate Impact, 54 AM. So('y CRIMINOI.)GY 680, 680 (2016).

203. See Ruha Benjamin, RAci: ArTi: Ti:cinology 10 (2019) "These tech advances are sold as morally superior because they purport to rise above human bias ..."); Sharad Goel et al., The Accuracy, Equity, and Jurisprudence of Criminal Risk Assessment, SSRN Eı.I.c. J. 1, 2 (2018) (comparing “clinical" predictions made by judges as gut instincts against " 'actuarial,' statistically based prediction[s]" in algorithmic risk assessment tools).

204. Professor Sandra Mayson popularized the phrase in the context of risk assessment tools from an adapted computer science idiom. Mayson, supra note 204, at 2224. But, the maxim has also been used in the broader conversation about inequalities in technology. E.g., Rashida Richardson et al., Dirty Data, Bad Predictions: How Civil Rights Violations Impact Police Data, Predictive Policing Systems, and Justice, 94 N.Y.U. L. Rrv. 192, 196-97 (2019) (using it in the context of predictive policing technologies). Jessi Hempel, Bias in, bias out: the Stanford scientist out to make AI less white and male, Post MAG. (Jan. 25, 2019, 6:00 AM), https://www.scmp.com/ magazines/post-magazine/long-reads/article/2183463/bias-bias-out-stanford-scientist-out-makeai-less (using it in the context of artificial intelligence).

205. Mayson, supra note 204, at 2251 . Other scholars have used the analogy of "zombie predictions," noting that because pretrial risk assessment tools are "developed on data that does not 
highly-speculative process of assessing defendant risk, ${ }^{206}$ at its core, projecting a mirror image of the past into the future by definition involves replicating existing patterns of inequity. ${ }^{207}$ It creates a feedback loop. ${ }^{208}$ And this replication is a byproduct of the essential nature of statistical predictions, which are inherently predicated on superimposing generalized data trends on individual defendants as if they are particularized facts. In other words, to analyze the relationship between an individual variable and its relationship to total risk level, a risk assessment tool must necessarily generalize an individual defendant's risk from the average rate of reoffense or flight for all offenders who share with the defendant the characteristics the tool used as variables; but - because individuals vary more than averaged groups-statistical generalization is hardly an accurate predictor of individual outcomes in particular cases. ${ }^{209}$ By using these past generalized group trends as predictions for the future risk of individual defendants, risk assessment tools reflect and reinforce the very patterns of inequity that bail reform works to change, ${ }^{210}$ risking integrating those disparities even deeper into the criminal system but now under a superficial promise of credibility.

These concerns about group-generalized predictions are only made more acute because risk assessment tools' predictions can only ever be as good as the data used to create them; so, when the existing data is in itself riddled with inaccuracies or biases, so too will be the predictions it generates. ${ }^{211}$ And the data currently used by risk assessment tools is flawed, not only as to its reliability for group generalizations, but also in its accuracy when measuring individual defendant's characteristics for use in each considered variable.

Risk assessment tools often use proxies to measure individual defendant's characteristics for the relevant variables-but those proxies can be dangerously misleading. For instance, when tools consider an individual's criminal history, the data proffered is not actually that of past crimes committed, but of past arrests serving as a proxy for prior criminality, even though arrests and crime commission do not necessa-

reflect changing ground realities," their predictions "may reanimate and give new life to old data and outcomes." Koepke \& Robinson, supra note 115, at 1755.

206. Stevenson, supra note 201, at 306.

207. Mayson, supra note 204, at 2251.

208. See Richardson et al., supra note 209, at 218-19.

209. Starr, supra note 205, at 842 (internal citation omitted).

210. Koepke \& Robinson, supra note 115, at 1759, 1764.

211. Mayson, supra note 204, at 2251; McGregor et al., supra note 203, at 317. 
rily align. ${ }^{212}$ And, because people of color are more likely to be arrested than White people engaged in the same unlawful behavior, using arrests as a proxy for criminal history may inaccurately portray certain defendants - those of color-as more "criminal" while underrepresenting the "criminality" of other-primarily Whitedefendants. ${ }^{213}$

Further, these individual discrepancies quickly add up so that when they are used to generate the generalized group averages, race-based disparities have already been inherently built in. For example, risk assessment tools may consider higher neighborhood crime rates as a positive predictor of an individual defendant's risk of reoffense. ${ }^{214} \mathrm{But}$ crime rates can be based on a rich history of racist-even unconstitutional-policing; this then injects and reinforces ingrained bias into the system so that now racist policing patterns are being used to predict reoffense. ${ }^{215}$ Scholars refer to this as the use of "dirty data"-data contaminated by "corrupt, biased, and unlawful practices ... as well as data that is distorted by individual and societal biases." 216 For instance, one analysis of predictive policing technologies (systems which, analogous to risk assessment tools, analyze historical police data to predict where a crime may occur and/or who will be involved, either as a victim or perpetrator) identified at least nine jurisdictions which collected police data for use in their predictive policing that temporally overlapped in whole or in part with "government investigations, consent decrees, or other [public] documentation of corrupt, racially biased, or otherwise illegal police practices" in the jurisdiction-i.e., that used dirty data. ${ }^{217}$ Consequently, in both predictive policing and risk assessment tools, when a geographic area is disproportionately targeted for unjustified policing, the area will be

212. Mayson, supra note 204 , at 2251-53 ("To determine who is likely to commit crime in the future, one would have to look at who has committed crimes in the past. But we do not know precisely who has committed crimes in the past. Most crimes are never reported; some are reported falsely; and crime reports do not reliably identify crime perpetrators. Law enforcement institutions strive to identify perpetrators, and toward that end they make arrests, file charges, and seek convictions. These institutional events are documented, but even the best law enforcement agency does not make an accurate arrest for every crime. Most crimes never result in arrest. Some arrests are erroneous. The same is true of filed charges and of convictions. So our record of past crimes is really a record of crime reports and law enforcement actions, and the relationship of that record to actual crimes committed is opaque."). See also Roberts, supra note 159 , at $1001-03$ (describing the ways in which arrests serve as a poor proxy for factual or legal guilt).

213. Goel et al., supra note 208 , at $7-8$.

214. Starr, supra note 205 , at $812-13$ (listing some of the factors used in COMPAS).

215. See Richardson et al., supra note 209 , at 196-97.

216. Id. at 195-96.

217. Id. at 197-98. 
overrepresented in the data used to predict reoffense in ways that suggest greater criminality. ${ }^{218}$ Thus, if a defendant lives in an area that is overpoliced due to unconstitutionally racist practices, such that the area has a purportedly higher crime rate, that overpoliced neighborhood can be used to justify a prediction that the defendant is "high risk" if released. Due to historic segregation, it is likely that a neighborhood policed with racist practices is poor and of color, and the individual defendant living there is also likely poor and of color. ${ }^{219}$ Suddenly, using neighborhood crime rates to predict reoffense has created the dangerous possibility that-because the variable is so closely correlated with race-risk assessment tools are actually using race to predict reoffense. ${ }^{220}$

And these concerns become only more pronounced because many developers of risk assessment tools increasingly create their tools as "black-box" mechanisms: they offer little to no transparency as to how their tools generate assessments or on what data. ${ }^{221}$ In fact, a Wisconsin defendant recently challenged that using a risk assessment tool in his sentencing to predict his risk of recidivating violated his constitutional due process rights "because the proprietary nature of COMPAS [the risk assessment tool] prevents defendants from challenging the COMPAS assessment's scientific validity." 222

218. Id. at 218 .

219. . Alex M. Johnson, Jr., How Race and Poverty Intersect to Prevent Integration: Destabilizing Race as a Vehicle to Integrate Neighborhoods, 143 U. PA. L. REV. 1595, 1606-16 (1995). See also Mayson, supra note 204, at 2263 (describing zip codes as "race-proxies").

220. Mayson, supra note 204, at 2222 ("Given that algorithmic crime prediction tends to rely on factors heavily correlated with race, it appears poised to entrench the inexcusable racial disparity so characteristic of our justice system, and to dignify the cultural trope of black criminality with the gloss of science.").

221. Stevenson, supra note 201, at 315-16; see also Richardson et al., supra note 209, at $197-98$.

222. State v. Loomis, 881 N.W.2d 749, 753 (Wis. 2016), cert denied, Loomis v. Wisconsin, 2017 U.S. LEXIS 4204 (June 26, 2017). The court ultimately rejected the defendant's due process argument on the basis that considering the risk assessment tool as a factor in sentencing, rather than as determinative, was constitutionally permissible. Id. at $770-71$. The court did caution, however, that the accuracy of risk assessment tools has recently been called into question by studies such as ProPublica's, see supra note 208 and accompanying text, so if a sentencing court is to use such tools in its decision-making process, it must acknowledge the tools' limitationsnamely:

(1) the proprietary nature of COMPAS has been invoked to prevent disclosure of information relating to how factors are weighed or how risk scores are to be determined; (2) risk assessment compares defendants to a national sample, but no cross-validation study for a Wisconsin population has yet been completed; (3) some studies of COMPAS risk assessment scores have raised questions about whether they disproportionately classify minority offenders as having a higher risk of recidivism; and (4) risk assessment tools must be constantly monitored and re-normed for accuracy due to changing populations and subpopulations. 
The net result of the flaws inherent in prediction and exacerbated by biased data is the creation of what Professor Ruha Benjamin calls the "New Jim Code"-a "digital caste system, structured by existing racial inequalities" that is "sold as morally superior because [it] purport[s] to rise above human biases" through technological advances but "could not exist without data produced through histories of exclusion and discrimination." 223 And these concerns have been borne out by empirical studies of risk assessment tools that find significant racial disparities in the tools' risk predictions, ${ }^{224}$ coupled with disbelief in such studies from tool developers ${ }^{225}$ and a paucity of solutions offered by researchers to de-bias the process. ${ }^{226}$

Id. at 763-64.

223. BI:NJAMIN, supra note 208 , at 10.

224. E.g., Melissa Hamilton, The Biased Algorithm: Evidence of Disparate Impact on Hispanics, 56 Ам. CRIM. L. Ri:v. 1553, 1577 (2019) ("Using multiple definitions of algorithmic unfairness, results consistently showed that COMPAS, a popular risk tool, is not well calibrated for Hispanics. The statistics presented evidence of differential validity and differential predictive ability based on Hispanic ethnicity. The tool fails to accurately predict actual outcomes in a linear manner and overpredicts risk for Hispanics. Overall, there is cumulative evidence of disparate impact."); Julia Angwin et al., Machine Bias, ProPulsı.L( $\wedge$ (May 23, 2016), https:// www.propublica.org/article/machine-bias-risk-assessments-in-criminal-sentencing (finding that COMPAS was only accurate at predicting defendants who would commit violent crime in the future $20 \%$ of the time, and it was nearly twice as likely to wrongly flag Black defendants for future criminality, even after controlling for criminal history, age, and gender). Contra Skeem \& Lowenkamp, supra note 207, at 700 ("At the most basic level, these results indicate that risk assessment is not 'race assessment'. . The [PCRA] strongly predicts rearrest for both Black and White offenders. Regardless of group membership, a PCRA score has essentially the same meaning, that is, the same probability of recidivism ... [And while] Black offenders tend to obtain higher scores on the PCRA than do White offenders[,] . . most (66 percent) of the racial difference in PCRA scores is attributable to criminal history - which strongly predicts recidivism for both groups, is embedded in current sentencing guidelines, and has been shown to contribute to disparities in incarceration. Finally, criminal history is not a proxy for race. Instead, criminal history partially mediates the weak relationship between race and a future violent arrest." (internal citation omitted)).

225. Northpointe, the developer of COMPAS, for instance, vociferously objected to ProPublica's findings that COMPAS was racially biased and fiercely defended the accuracy of COMPAS's risk assessments. Angwin et al., supra note 229.

226. For instance, merely using race-neutral, colorblind assessments is unlikely to resolve the bias issues in predictive algorithms. Professor Sandra Mayson offers the illustration that in her experience as a New Orleans public defender, the significance of arrests varied by race:

If a black man had three arrests in his past, it suggested only that he had been living in New Orleans. Black men were arrested all the time for trivial things. If a white man, however, had three past arrests, it suggested that he was really bad news! White men were hardly ever arrested; three past arrests indicated a highly unusual tendency to attract law enforcement attention. A race-blind algorithm would not observe this difference. It would treat the two men as posing an identical risk. The algorithm could not consider the arrests in the context of disparate policing patterns and recognize that arrests were a much less significant indicator of risk for a black man than for a white man. It would perpetuate the historical inequality by overestimating the black man's 
Nowhere is this phenomenon more evident than in New Jersey. Widely hailed as one of the most progressive reforms in the modern era of bail reform, New Jersey overhauled its bail system in 2017 after a 2013 bombshell report by the Drug Policy Alliance found that $73.3 \%$ of individuals held in the New Jersey County Jail System on any given day in 2012 were pretrial detainees awaiting trial; and these defendants would be jailed, on average, 139 days awaiting appearance before a grand jury, 314 days awaiting trial, and 324 days awaiting sentencing. ${ }^{227}$ More concerningly, the report concluded that $38.5 \%$ of the total jail inmate populate was detained solely due to their financial inability to post bail, even when their bail amounts were relatively small. ${ }^{228}$ Consequently, three months after the publication of the report, New Jersey established the Joint Committee on Criminal Justice to address bail-related issues. ${ }^{229}$ Recognizing that pretrial detainees are more likely to plead guilty, be convicted, be sentenced to prison, and receive harsher prison sentences than released detainees, ${ }^{230}$ the Committee recommended "a statutory change from [New Jersey's] present 'resource-based' system" to one that "employs an objective, 'risk-based' method of analysis to assess a defendant's risk of failure to appear and danger to the community."231 The Committee argued that the risk-based bail system was more likely to promote "societal interests in both the defendant's liberty and the community's safety" than a wealth- or resource-based system and that "a risk-based system is more fair to a defendant because the assessment of risk level is based upon objective factors unrelated to indigency, race or ethnicity."232 Based on the Committee's report, the Legislature passed comprehensive legislation in the summer of 2014 and voters passed a

relative riskiness and underestimating the relative riskiness of the white man. A colorblind algorithm might therefore discriminate on the basis of race.

Mayson, supra note 204, at 2264.

227. Marie Vannostrand, Drug Pollicy Alliance, New Jersey Jail Population ANALYSIS 11-12 (Mar. 2013), https://www.drugpolicy.org/sites/default/files/New_Jersey_Jail_Pop ulation_Analysis_March_2013.pdf.

228. Id. at 13.

229. N.J. Sup. Ct. Joint Comm. Crim. Just., Report of the Joint Committee on CrimiNAL JUSTICE 1 (Mar. 10, 2014), https://www.njcourts.gov/courts/assets/criminal/finalreport3202014.pdf. Led by Supreme Court Chief Justice Stuart Rabner, the Committee was "comprised of judges, prosecutors, public defenders, private counsel, court administrators and staff from the Legislature and Governor's office." Id. It also recommended speedy trial-related improvements, which were also then implemented in the legislative reforms, see infra note 238 and accompanying text, but this paper focuses exclusively on the bail-related portion of the reforms. Id.

230. Id. at $1-2$.

231. Id. at 2.

232. Id. at 11 . 
constitutional amendment that November implementing the recommended change from a wealth to a risk-based system, to take effect on January 1, 2017..$^{233}$

Under the new risk-based system, courts may only order pretrial detention of an eligible defendant, ${ }^{234}$ on motion of the prosecutor, ${ }^{235}$ "when it finds clear and convincing evidence that no condition or combination of conditions can reasonably assure" (1) the "defendant's appearance in court when required, [(2)] the protection of the safety of any other person or the community, [(3)] that the [] defendant will not obstruct or attempt to obstruct the criminal justice process, and [(4)] that the [] defendant will comply with all conditions of release." 236 Further, the law creates a strong presumption against monetary bail, which can only be set if "no other conditions of release will reasonably assure" the defendant's subsequent appearance. ${ }^{237}$ Thus, from most restrictive to least restrictive, pretrial defendants may be either (1) released on their own recognizance ("ROR"), (2) released on non-monetary conditions (which must be the least restrictive conditions necessary), (3) released on monetary bail, or (4) detained in jail; and courts may increase restrictions from ROR only if necessary to assure appearance, protect public safety, or maintain an unobstructed criminal process. ${ }^{238}$ In determining which level of restriction is appropriate for a defendant, the court may consider, inter alia, the predictions of its pretrial risk assessment tool, the Public Safety Assessment ("PSA"). ${ }^{239}$

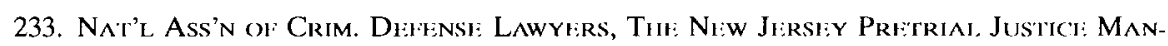
UAI, 6 (Dec. 12, 2016), https://www.nacdl.org/Document/NewJerseyPretrialAdvocacy.

234. Almost any defendant is eligible for detention on motion of the prosecutor. N.J. SiAT. ANN. $\$ 2 A: 162-19$ (West 2019) (articulating specific crimes which may render a defendant eligible for pretrial detention but concluding with a catch-all that prosecutors may also move to detain a defendant for "any other crime for which the prosecutor believes there is a serious risk" the defendant will not appear, will pose a danger, or will obstruct the criminal process).

235. If the prosecutor moves for detention, such motion will create a "rebuttable presumption that the eligible defendant shall be detained pending trial because no amount of monetary bail, non-monetary condition or combination of monetary bail and conditions would reasonably assure" appearance, public safety, and an unobstructed process. Id. $\$ 2 \mathrm{~A}: 162-19$ (b).

236. Id. \$ 2A:162-15.

237. $I d$.

238. Id. $\$ 2 \mathrm{~A}: 162-17$. Detention is more likely in cases involving domestic violence, where the risk of harm if a defendant is released is more acute. $I$ d. $\$ 2 \mathrm{~A}: 162-18$.

239. N.J. StAT. ANN. $\$ 2 A: 162-20$ (West 2019). Other relevant factors include the nature and circumstances of the offense charged; the weight of the evidence against the defendant (including considerations of what may be subsequently held inadmissible); the history and characteristics of the defendant (e.g., defendant's character, family and community ties, employment, physical and mental fitness, criminal history, etc.); and the nature and seriousness of the danger release would pose either to any person or to the community or to an unobstructed criminal 
The PSA analyzes nine "objective" risk factors 240 to produce separate scores of a defendant's risk of, if released, failing to appear ("FTA score") or committing new criminal activity ("NCA score") on a six-point scale. It also flags if a defendant is likely to commit new violent criminal activity if released. ${ }^{241}$ To translate these scores to a release recommendation, the court must first determine if any circumstances or charges are present that would produce a recommendation the defendant be detained pretrial without opportunity for release, regardless of the PSA score. ${ }^{242}$ If none of these conditions exist, the court will then look to the Decision Making Framework Matrix ("DMF Matrix"), which plots the defendant's FTA scores against their NCA scores to generate a recommendation for or against release and on what conditions, where increases in either or both scores correspond to heightened restrictions. ${ }^{243}$ For instance, a defendant for whom the PSA produces an NCA and FTA score of 2, the DMF Matrix recommends ROR; if, however, the defendant's NCA score is 4, then the DMF Matrix recommends a Pretrial Monitoring Level ("PML") of 2, which would require the defendant contact pretrial services by phone and face-to-face once per month. ${ }^{244}$

process. Id. See also id. $\$ 2 \mathrm{~A}: 162-25$ (c) (establishing the use of a risk assessment instrument in determination of pretrial release).

240. N.J. CourTs, Public Safety Assessment (Dec. 2018), https://www.njcourts.gov/courts/assets/criminal/psariskfactor.pdf?c=Y8K. The risk factors are: (1) the defendant's age at current arrest; (2) if the current offense is violent; (3) whether any charges were already pending at the time of the offense; the existence of any prior convictions for (4) disorderly persons offenses, (5) indictable or felony offenses, or (6) violent offenses, all in-state or out-of-state; whether the defendant failed to appear pretrial (7) in the past two years or (8) more than two years ago; and (9) if the defendant was previously sentenced to incarceration for any offense. Id.

241. Id. at 5-7. For more information on how the PSA converts the risk factors into NCA and FTA scores, see National Association of Criminal Defense Lawyers, supra note 238, at $8-9$.

242. N.J. Courts, Pretrial Release Decision Making Framework 1 (Mar. 2018), https:// www.njcourts.gov/courts/assets/criminal/decmakframwork.pdf?c=2Je. Such circumstances or charges include if any current charge is subject to life imprisonment; if the PSA generated a risk of $6 / 6$ as to the defendant's risk of failing to appear or new criminal activity; if the PSA generated a flag for new violent criminal activity and one of the current charges is violent; if any current charge is one of the enumerated offenses of particular concern (i.e., escape, aggravated manslaughter or manslaughter, aggravated sexual assault or sexual assault, first degree robbery, carjacking, and certain weapons offenses); or if the defendant has previously been arrested on two separate occasions and those charges were still pending at the time of the current offense. Id.

243. Id. at 2, 4. The court must increase the restrictions recommended by one "level" if any current charge is subject to the No Early Release Act not already addressed or is an enumerated weapons charge. $I d$. at 2 .

244. Id. at 3-4. Defendants with NCA and FTA scores of 1-2 are recommended for ROR. Id. at 4. Defendants with FTA 3-4 and NCA 2-3 are recommended for PML 1, which requires phone contact with pretrial services once per month. Id. at 3-4. Defendants with NCA 4 and FTA 2-4 or with FTA 5 and NCA 2-3 are recommended for PML 2. Id. Defendants with NCA 4 and FTA 
Under this new risk-based PSA system, New Jersey has seen a $44.1 \%$ decrease in its pretrial detainee population from December 31 , 2015 to December 31,2019.245 In 2019, 17.6\% of bail eligible defendants $(n=7.456)$ were detained pretrial. ${ }^{246}$ And, in the first 22 months of the new system's use, the percentage of defendants held on bail of less than $\$ 2,500$ dropped from $12 \%$ in 2012 to $4.6 \%$ in $2018 . .^{247}$ Also, the charge distribution for pretrial detainees showed that pretrial detainees post-reform were more likely to be held on serious charges than pre-reform, where many detainees were only facing minor or nonviolent charges. ${ }^{248}$ Further, these reforms did not result in a significant increase in new criminal activity or failures to appear. ${ }^{249}$ Consequently, New Jersey hails its bail reforms as a success, asserting that its reform "is operating as intended and has resulted in a fairer criminal justice system" and that the PSA "is an accurate and effective tool that is working as expected." 250

But this rosy outlook ignores that Black pretrial detainees still make up a disproportionate percentage of the jail population. Indeed, the racial makeup of New Jersey jails has remained disconcertingly constant. ${ }^{251}$ And Black detainees remain detained, on average, for nearly twice as long as White detainees. ${ }^{252}$ This necessitates asking why the purported benefits of New Jersey's bail reform have not reached all detainees equally and raises serious doubts about the PSA's ability to produce truly unbiased assessments.

Consequently, the efficacy of bail reform movements favoring "objective" pretrial risk assessment tools cannot be said to have rectified the access to justice issues perpetrated by cash bail. Firstly, while bail

5 or with NCA 5 and FTA 2-4 are recommended for PML 3, which requires phone contact with pretrial services once every other week and face-to-face contact once every other week. Id. Finally, for defendants with both an FTA and NCA of 5, PML 3 is recommended, accompanied by electronic (i.e., GPS) monitoring or home detention. Id. Recall that defendants with either or both a 6 on FTA or NCA are recommended not to be released. Id. at 3 .

245. N.J. Cour'rs, Criminal Justice Reform, Chart C (2019), https://njcourts.gov/courts/assets/ criminal/cjrreport2019.pdf?c=HSH.

246. Id. at Chart A.

247. N.J. Courts, Ri:POrT TO TIE. Govi:Rnor ani) Li:gislatituri: 25 (2018), https:// www.njcourts.gov/courts/assets/criminal/2018cjrannual.pdf?c=OWB.

248. Id. at 26,45 .

249. The percentage of defendants charged with a new indictable crime while awaiting trial changed from $12.7 \%$ to $13.7 \%$ from 2014 to 2017 , and from $11.5 \%$ to $13.3 \%$ for disorderly persons offenses. $I d$. at 13 . Defendants appeared at slightly lower rates for pretrial court appearances in $2017(89.4 \%)$ than in $2014(92.7 \%)$, but " $\mathrm{t}$ ] he similar rates of cases disposed [from 2014 to 2017] . . . suggest that defendants are returning for trial after missing an appearance and not fleeing." Id. at 15 .

250. Id. at 45 .

251. Id. at 7,27 .

252. Id. at $20-21$. 
reform like that in New Jersey, which creates a strong presumption against cash bail or pretrial detention, may reduce the size of pretrial jail populations, ${ }^{253}$ it does nothing in itself to alleviate the inherent harms of pretrial detention on case outcomes that created the procedural access to justice injuries in the first instance-i.e., a reduced or nonexistent presumption of innocence, inadequate defense opportunities, a de facto burden shift from the state to the defendant, and coercive pressures to plead guilty. ${ }^{254}$ Further, the fact that the reduction in jail population has not accrued proportionally across all racial groups $^{255}$ suggests that some defendants who should have seen the benefits of bail reform are yet unable to access it; so, to at least some extent, the burden of the pretrial detention harms is still being applied to defendants for reasons other than necessity (i.e., public safety or flight risk).

Secondly, as to structural access to justice harms, risk-based bail reforms demonstrably do not improve concerns regarding the impartiality of tribunals or equal court access. ${ }^{256}$ Instead, they seem to substitute wealth for race: rather than detaining the poor on account of their poverty through cash bail, bail reform detains people of color on account of their race through biased risk assessment tools. ${ }^{257}$ And, because people of color disproportionately comprise the poor, ${ }^{258}$ it is also not unlikely that the same individuals are being detained pretrial and denied equal access under both systems. Either way, the result remains the disproportionate pretrial detention of a class of defendants-who now suffer the harms of detention-on account of their identity status, in direct contravention of the principle of equal access. It is no improvement in human rights to swap classism for racism. ${ }^{259}$ Additionally, the potential for abuse or violation of the competency requirement of structural access to justice is heightened in the context of algorithmic risk assessment tools because of concerns that these black-box technologies are making adjudicatory decisions on behalf of

253. See supra notes $250-51$ and accompanying text.

254. See supra notes $185-86,190-94$ and accompanying text.

255. See supra notes $217-25,228-31,252-53$ and accompanying text.

256. See supra notes 73-78 and accompanying text; see supra Part II.C.

257. . See supra notes 217-25, 228-31 and accompanying text.

258. . Johnson, supra note 224 , at $1606-16$.

259. This is not to say that the cash bail system that detains the poor for their poverty is not also imbued with gross racism, such that a move to a risk-based system neatly and wholly replaces one form of bias with another. The unfortunate underbelly of intersectionality means that racism and classism likely operate in both bail systems - those predicated on cash bail and those which use algorithmic risk assessment tools-in tandem and against the same folks; the primary difference between the two systems is which bias more predominates as a system motivation, relative to the other. 
the state, in lieu of statutorily- or constitutionally-created tribunals. ${ }^{260}$ Together, these two harms represent exacerbated concerns regarding court impartiality: regardless whether judges are using algorithmic pretrial risk assessment tools as a factor or as the determinant in release, the bias inherent in the tools is more firmly integrating racial inequities into the criminal system as a result of the tools' mere use. And, the "sheen of scientific credibility" under which the tools hide potentially also renders the more-integrated bias simultaneously less objectionable to those who reject findings of the tools' bias and less easily identifiable to those seeking to search for it, as may be the case in New Jersey. Thus, existing bail reforms fail to vindicate defendants' human right of access to justice.

\section{CONCLUSION}

Cash bail results in the disproportionate pretrial detention of the poor on account of their inability to afford to buy their release, resulting in adverse case outcomes both in conviction and in sentencing, as facilitated by the most insidious facets of plea bargaining. That both the detention of the poor and the harms of pretrial detention have been judicially recognized but remain unremedied signifies the need to turn to an alternate means of demanding change: the human right of access to justice. The phenomenon of cash bail undermines defendants' human right of access to justice structurally - by denying equal court access and tribunal impartiality, as well as potentially outsourcing adjudicatory functions from competent tribunals-and procedurally-by eroding the presumption of innocence, practically shifting the burden of proof, placing undue coercive influence on defendants to plead guilty, and curtailing opportunities for defendants to present adequate defenses. Further, these access to justice issues are not resolved by existing bail reforms but are rather exacerbated by them due to the increasing use of pretrial risk assessment tools that replicate existing inequities and etch racial biases deeper into the criminal system, all under the veneer of science.

The principles of human rights thus serve as a more just lens through which to understand the urgent imperative to effectively reform the cash bail system. Additionally, the rhetoric and norms of human rights reflect that the current bail system is objectively a grave

260. This concern parallels that of Eric Loomis, the Wisconsin defendant challenging the use of COMPAS in his sentencing as a due process violation. State v. Loomis, 881 N.W.2d 749, 753 (Wis. 2016), cert denied, Loomis v. Wisconsin, 2017 U.S. LEXIS 4204 (June 26, 2017); see supra note 227 and accompanying text. 
legal concern, not merely a moral failing. ${ }^{261}$ The human right of access to justice also offers standardized, internationalized norms by which to measure the adequacy of reforms and ensure their effectiveness. Bail reform advocates should therefore demand effective bail reform solutions that vindicate defendants' human right of access to justice. Following the lead of a growing number of "human rights cities" that expressly incorporate human rights norms into their policies and programs at large, jurisdictions should work towards policies that actualize the human rights of their residents in the context of effective bail reform. ${ }^{262}$

The longer these harms go unremedied, the more defendants suffer collateral consequences in their housing, employment, voting, and other opportunities; ${ }^{263}$ the more abusive policing practices, like those in Ferguson, are allowed to fester rather than incentivized to change;264 the more poor people are traumatized and stigmatized;265 and the more headlines bear stories like those of Kalief Browder, Sandra Bland, Janice Dotson-Stephens, or Layleen Cubilette-Polanco. At least in their names, we must vindicate access to justice.

261. See supra notes $48-49$ and accompanying text.

262. Jackie Smith, Local Responses to Right-Wing Populism: Building Human Rights Cities, 11 STud. Soc. Just. 347, 348-49, 353-54 (2017). This would not necessarily violate principles of federalism, as many human rights concerns fall within the ambit of state police powers "where the federal government is more likely to acknowledge that subnational jurisdictions have some independent authority." Martha F. Davis, The Upside of the Downside: Local Human Rights and the Federalism Clauses, 62 ST. Louis U. L.J. 921, 937 (2018); see also id. at 931-32, 938 (recommending local governments "take the lead in treaty implementation and human rights realization" when the rights touch local responsibilities and suggesting "the United States violates its treaty obligations... when it interferes with local human rights initiatives that are furthering U.S. treaty objectives and that ware within the purview of local actors").

263. Heaton et al., supra note 85 , at 714 .

264. See supra notes $127-134$ and accompanying text.

265. Alston, supra note 190, 972. 
